\title{
Temperature effects on the spatial structure of heavy rainfall modify catchment hydro-morphological response
}

\author{
Nadav Peleg ${ }^{1}$, Chris Skinner ${ }^{2}$, Simone Fatichi $^{1}$, and Peter Molnar ${ }^{1}$ \\ ${ }^{1}$ Institute of Environmental Engineering, ETH Zurich, Zurich, Switzerland \\ ${ }^{2}$ Energy and Environment Institute, University of Hull, Hull, UK \\ Correspondence: Nadav Peleg (nadav.peleg@ @scer-soe.ethz.ch)
}

Received: 15 August 2019 - Discussion started: 16 September 2019

Revised: 5 November 2019 - Accepted: 5 December 2019 - Published: 17 January 2020

\begin{abstract}
Heavy rainfall is expected to intensify with increasing temperatures, which will likely affect rainfall spatial characteristics. The spatial variability of rainfall can affect streamflow and sediment transport volumes and peaks. Yet, the effect of climate change on the small-scale spatial structure of heavy rainfall and subsequent impacts on hydrology and geomorphology remain largely unexplored. In this study, the sensitivity of the hydromorphological response to heavy rainfall at the small-scale resolution of minutes and hundreds of metres was investigated. A numerical experiment was conducted in which synthetic rainfall fields representing heavy rainfall events of two types, stratiform and convective, were simulated using a space-time rainfall generator model. The rainfall fields were modified to follow different spatial rainfall scenarios associated with increasing temperatures and used as inputs into a landscape evolution model. The experiment was conducted over a complex topography, a medium-sized $\left(477 \mathrm{~km}^{2}\right)$ Alpine catchment in central Switzerland. It was found that the responses of the streamflow and sediment yields are highly sensitive to changes in total rainfall volume and to a lesser extent to changes in local peak rainfall intensities. The results highlight that the morphological components are more sensitive to changes in rainfall spatial structure in comparison to the hydrological components. The hydromorphological features were found to respond more to convective rainfall than stratiform rainfall because of localized runoff and erosion production. It is further shown that assuming heavy rainfall to intensify with increasing temperatures without introducing changes in the rainfall spatial structure might lead to overestimation of future climate impacts on basin hydro-morphology.
\end{abstract}

\section{Introduction}

Changes in climate can impose modifications to fluvial systems that sometimes exceed the historical natural variability (Blum and Tornqvist, 2000; Fatichi et al., 2014; Goudie, 2006; Vandenberghe, 1995). These include, for example, changes to river mean streamflow, frequency and magnitude of floods, channel morphology, catchment connectivity, and changes to sediment yields (Blöschl et al., 2017; Coulthard et al., 2012b; Hancock, 2009; Lane et al., 2017; Tucker and Slingerland, 1997). The fluvial system is particularly sensitive to climate extremes, such as extreme rainfall events that can trigger landslides (Leonarduzzi et al., 2017), debris flows (Amponsah et al., 2016; Borga et al., 2014; Destro et al.,
2018), or floods (Mallakpour and Villarini, 2015; Marchi et al., 2010) that may rapidly change the landscape and river system (Death et al., 2015; Krapesch et al., 2011; Thompson and Croke, 2013).

Spatio-temporal rainfall variability has been shown to play an important role in the hydro-morphological response of small- to medium-sized catchments (i.e. of the order of $10^{1}-$ $10^{3} \mathrm{~km}^{2}$ ), affecting streamflow and sediment transport volumes, peaks, and time to peaks (Arnaud et al., 2011; Bahat et al., 2009; Coulthard and Skinner, 2016; Kampf et al., 2016; Morin et al., 2006; Paschalis et al., 2014; Singh, 1997; Yakir and Morin, 2011; Zhu et al., 2018; Zoccatelli et al., 2011). Heavy rainfall events at these spatial scales have the potential to cover a given catchment entirely, thus increas- 
ing the sensitivity of the hydro-morphological response to the extreme event itself (Do et al., 2017; Sharma et al., 2018; Wasko and Sharma, 2017). The impact of rainfall variability on hydro-morphological response is more significant in climate regimes where a substantial part of the rainfall is associated with convective events (Belachsen et al., 2017; Goodrich et al., 1995; Kampf et al., 2016; Peleg and Morin, 2012; Wright et al., 2013), and it is most pronounced when heavy rainfall events are considered (Marra and Morin, 2018; Peleg et al., 2018b). Therefore, rainfall fields at high spatial and temporal resolutions which are suitable to capture rainfall convective features (i.e. $1 \mathrm{~km}$ and $10 \mathrm{~min}$, or finer) are desirable for hydrological and geomorphological climate change impact studies (Coulthard and Skinner, 2016; Gires et al., 2015; Li and Fang, 2016; Morin et al., 2006; OchoaRodriguez et al., 2015; Peleg et al., 2015; Skinner et al., 2020; Zhu et al., 2018).

Changes in heavy rainfall in recent decades, such as extremely long wet spells and rainfall intensification, have been reported in different regions (Alexander et al., 2006; Fischer and Knutti, 2016; Peterson et al., 2013; Singh et al., 2014; Westra et al., 2013). The intensity of heavy rainstorms is sensitive to warming (e.g. Berg et al., 2013; Molnar et al., 2015) due to warmer air having an increased water vapour holding capacity, which in saturated conditions follows the Clausius-Clapeyron (CC) relationship (O'Gorman and Schneider, 2009; Pfahl et al., 2017; Trenberth et al., 2003). The characteristics of heavy rainfall, such as intensity, frequency, and duration, are foreseen to continue changing as a consequence of increasing emissions of anthropogenic greenhouse gases and thus increasing temperatures in the future (Fischer et al., 2013; Fischer and Knutti, 2015; Orlowsky and Seneviratne, 2012).

Only a few studies have used observed data, obtained from dense rain-gauge networks or from weather radar estimates, to analyse the impact of increasing temperatures on the spatial characteristics of heavy rainfall (e.g. Berg et al., 2013; Lochbihler et al., 2017; Peleg et al., 2018a; Wasko et al., 2016). Although similar methods were employed, different results were reported for various regions and climates. Wasko et al. (2016) reported a redistribution of available water vapor from the low-intensity regions of the rain field toward the high-intensity regions for tropical, temperate, and arid climates in Australia, meaning that while the peak rainfall of the storm is intensifying the area of the heavy rainfall reduces with increasing temperatures (case 1, Fig. 1). Peleg et al. (2018a) observed similar trends of changes in spatial rainfall characteristics for the Mediterranean climate; however, for semi-arid to arid climates (east Mediterranean region) they found that while higher temperatures lead to an increase in the peak intensity of heavy rainfall the area of the heavy rainfall remains largely unchanged or only slightly reduces, with a small weakening in total rainfall amounts (case 2, Fig. 1). Lochbihler et al. (2017) observed that both the area and the intensity of heavy rainfall increase with ris-

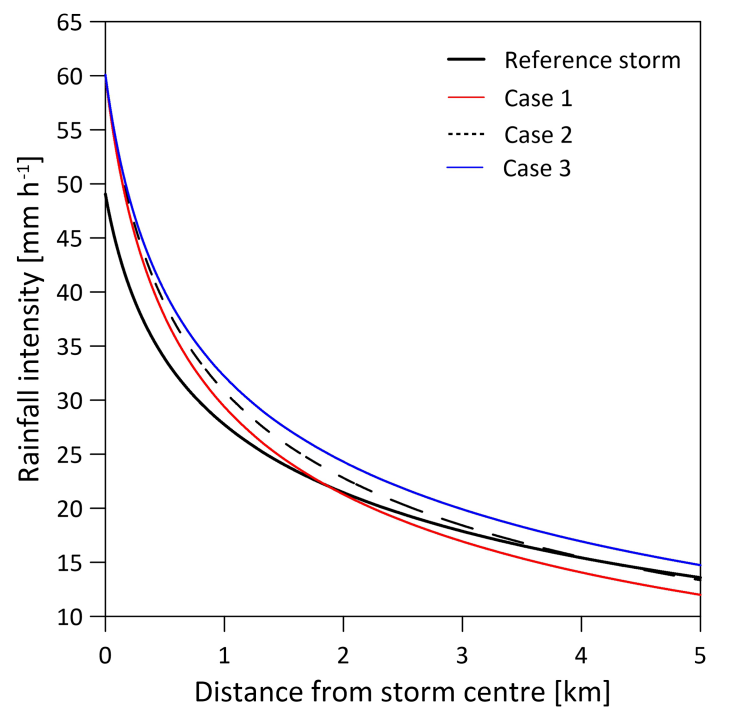

Figure 1. Graph of the changes to the spatial structure of storms with increasing temperature. The peak of the storm is at the storm's centre and the rainfall intensities follow a log-normal decay with distance from the centre. The black line represents a storm for an arbitrary temperature (reference storm). Other lines (cases 1 to 3 ) represent plausible storm profiles with higher temperature, which lead to an intensified rainfall peak but differences in areal rainfall and area of heavy rainfall (see text for details).

ing temperatures for the temperate maritime climate in the Netherlands (case 3, Fig. 1). The effect of temperature on the small-scale spatial structure of heavy rainfall varies across locations, likely due to differences in climate dynamic conditions and available humidity (Pfahl et al., 2017), and this remains largely unexplored for many regions worldwide.

The future space-time structure of heavy rainfall at the small scale can be inferred from two main sources. The first option is by simulating rainfall using a convection-permitting model (CPM). Convective processes are represented explicitly in CPMs based on the governing dynamical equations (Ban et al., 2014, 2015; Prein et al., 2015) that allow for the representation of the space-time structure of rainfall directly at the small scale, i.e. without the need for further downscaling or applying de-biasing procedures. Prein et al. (2017), for example, used a CPM to simulate how the rainfall space-time structure is changing in future climate over the US. However, the CPM approach for simulating future rainfall comes with a drawback: it is highly demanding in terms of computational resources because high-performance computing is needed to run the models. An alternative option is to use space-time stochastic rainfall generator models (Benoit et al., 2018a; Paschalis et al., 2013; Peleg et al., 2017b; Peleg and Morin, 2014; Singer et al., 2018) to simulate rainfall based on information derived from weather radar for the present and regional climate models (RCMs) for the future. RCMs simulate rainfall fields at a spatial resolution not far from what is needed in local impact studies (e.g. some EURO- 
CORDEX models are at $11 \mathrm{~km}$ resolution; Jacob et al., 2014), but they do not resolve convection processes explicitly. Nevertheless, some of the rainfall spatial properties can be properly represented by RCMs if appropriate convective parameterizations are used, as recently discussed by Li et al. (2018). Changes in rainfall simulated by RCMs should be combined with proper observations of the space-time rainfall structure at small scale, obtained from dense rain-gauge networks or weather radars (Benoit et al., 2018b; O and Foelsche, 2019; Peleg et al., 2013), and from the relationship between the rainfall spatial properties and other climate variables like near-surface air temperature or dew point temperature (Berg et al., 2013; Mishra et al., 2012; Molnar et al., 2015; Westra et al., 2014). The main shortcomings of this alternative are that the information needed is not readily available for many locations and that the approach relies on the strong assumption that the rainfall-temperature relationships of the present climate hold true for the future (Peleg et al., 2019).

Therefore, in order to investigate the impacts of temperature-induced changes in rainfall on the hydromorphological response of catchments, expert knowledge in setting and operating climate models or rainfall generators is required. This is likely the reason why the question of the sensitivity of hydro-morphological response to spatial changes in high-resolution rainfall fields has not been extensively explored so far, and only a few studies have analysed geomorphological implications of climate impacts using stochastic approaches or distributed rainfall (e.g. Coulthard and Skinner, 2016; Francipane et al., 2015). The "geomorphic multiplier" concept (Coulthard et al., 2012b), i.e. the non-linear relation between streamflow and sediment yield, emphasizes the importance of answering the question at hand, as the effects of rainfall structure on runoff are relatively well studied, yet the effects on sediment production and transport are still largely unidentified.

In this study, we aim to explore the sensitivity of the hydromorphological response to rainfall at the convective scales of minutes and hundreds of metres, which are the relevant scales for the hydrological response of small- and medium-sized catchments. To this end, a numerical experiment was conducted in which synthetic rainfall fields representing a typical heavy rainfall event were simulated. The rainfall fields were then modified to follow different plausible spatial rainfall scenarios, associated with increasing temperatures, and used as climatic forcing in the combined landscape evolution and floodplain model CAESAR-Lisflood to simulate hydromorphological response. The numerical experiment was conducted in a medium-sized Alpine catchment with a complex topography (Kleine Emme, central Switzerland, $477 \mathrm{~km}^{2}$ ). The sensitivity of the hydro-morphological response to the rainfall spatial properties, the implications for climate change impact studies, the generalization of the results, and the limitations of the numerical experiment are discussed. The approach also provides an example of how uncertainties in cli- mate change impact assessments and their propagation into hydro-morphological response could be framed.

\section{Methods}

\subsection{Experimental setup}

The sensitivity of catchment hydro-morphological response to changes in the spatial properties of rainfall during heavy rainfall events was examined using a combination of models. The numerical experiment is composed of two steps: (i) generation of an ensemble of space-time rainfall fields under scenarios of temperature change, and (ii) simulation of hydromorphological response in runoff and sediment yield with this ensemble.

First, a time series of mean areal rainfall over the domain is simulated. The time series follows a temporal structure of a design storm characterized by a Gaussian shape that is assumed representative of a heavy rainfall event for present climate conditions (Fig. 2). A rainfall generator model (Sect. 2.2) is then used to generate multiple realizations of gridded rainfall for the design storm. In practice, the rainfall generator downscales the areal rainfall over the domain to a finer spatial resolution. Each of the realizations has a different 2-dimensional representation of the rainfall intensities in space. In this way, the spatial rainfall variability (stochasticity) is explicitly accounted for (see further discussion on the role of stochastic rainfall spatial variability by Paschalis et al., 2014; Peleg et al., 2017a, 2018b, 2019). The model was set to simulate two types of rainfall: stratiform and convective, with associated values of peak rainfall intensities and spatial variability in rainfall intensity (see Sect. 3.2).

The rainfall fields are then modified using the rainfall generator to follow four "temperature increase scenarios" and four "areal rainfall scenarios" for convective and stratiform types $(16 \times 2$ spatial scenarios altogether, see Table 1$)$. In all of the scenarios, the peak rainfall intensity at the grid scale (i.e. the grid cells with the maximum rainfall intensities at the time the areal rainfall peaks) is assumed to intensify at a rate of $7 \%{ }^{\circ} \mathrm{C}^{-1}$, which corresponds to the $\mathrm{CC}$ rate (Trenberth et al., 2003) and is representative of a fully saturated air column. The areal rainfall scenarios refer to four possible cases: (case 1) a decrease in the mean areal rainfall (by $-3 \%{ }^{\circ} \mathrm{C}^{-1}$ ) that is associated with a decrease in the area of heavy rainfall (defined as the total area above a rain intensity threshold of $10 \mathrm{~mm} \mathrm{~h}^{-1}$ ), (case 2) no change in the mean areal rainfall $\left(0 \%{ }^{\circ} \mathrm{C}^{-1}\right)$ but a small decrease in the area of heavy rainfall, (case 3) an increase in the mean areal rainfall (by $3 \%{ }^{\circ} \mathrm{C}^{-1}$ ) with a small increase in the area of heavy rainfall, and (case 4) an increase in the mean areal rainfall of the same rate as peak rainfall $\left(7 \%{ }^{\circ} \mathrm{C}^{-1}\right)$ with a significant increase in the area of heavy rainfall (Table 1 and Fig. 1).

Peak rainfall intensity can intensify at a higher rate than $7 \%{ }^{\circ} \mathrm{C}^{-1}$, potentially increasing the consequences for the 


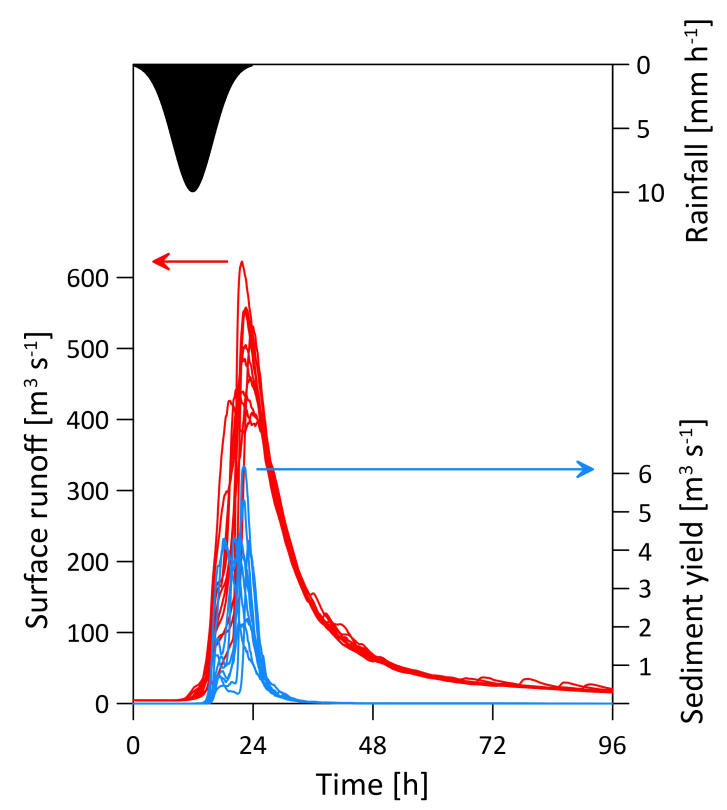

Figure 2. Illustration of the mean rainfall intensity over the catchment area for the design storm (black area) and the respectively generated stream runoff (red lines) and sediment yields (blue lines) from 10 stochastic rainfall realizations produced with the rainfall generator model.

Table 1. The four "temperature increase scenarios" $(\Delta T)$, and the four scenarios for changes in the mean areal rainfall intensity (expressed by $\%{ }^{\circ} \mathrm{C}^{-1}$ ). The scenarios apply for both stratiform and convective types, with different peak intensities and spatial statistical properties of rainfall. Colours represent qualitatively changes in the area of the intense rainfall, from a large increase (dark blue) to a large decrease (dark green). For all the scenarios, the peak rainfall intensity is assumed to increase at a rate of $7 \%{ }^{\circ} \mathrm{C}^{-1}$.

\begin{tabular}{ccccc}
\hline Case & $\Delta \mathrm{T}=1{ }^{\circ} \mathrm{C}$ & $\Delta \mathrm{T}=2^{\circ} \mathrm{C}$ & $\Delta \mathrm{T}=3{ }^{\circ} \mathrm{C}$ & $\Delta \mathrm{T}=4^{\circ} \mathrm{C}$ \\
\hline 1 & $-3 \%{ }^{\circ} \mathrm{C}^{-1}$ & $-3 \%{ }^{\circ} \mathrm{C}^{-1}$ & $-3 \%{ }^{\circ} \mathrm{C}^{-1}$ & $-3 \%{ }^{\circ} \mathrm{C}^{-1}$ \\
2 & $0 \%{ }^{\circ} \mathrm{C}^{-1}$ & $0 \%{ }^{\circ} \mathrm{C}^{-1}$ & $0 \%{ }^{\circ} \mathrm{C}^{-1}$ & $0 \%{ }^{\circ} \mathrm{C}^{-1}$ \\
3 & $3 \%{ }^{\circ} \mathrm{C}^{-1}$ & $3 \%{ }^{\circ} \mathrm{C}^{-1}$ & $3 \%{ }^{\circ} \mathrm{C}^{-1}$ & $3 \%{ }^{\circ} \mathrm{C}^{-1}$ \\
4 & $7 \%{ }^{\circ} \mathrm{C}^{-1}$ & $7 \%{ }^{\circ} \mathrm{C}^{-1}$ & $7 \%{ }^{\circ} \mathrm{C}^{-1}$ & $7 \%{ }^{\circ} \mathrm{C}^{-1}$ \\
\hline
\end{tabular}

fluvial response. To further demonstrate this point, a subset of the numerical experiments (case 2 and only for the convective rainfall type) was extended to include intensification of the peak rainfall at the grid scale from the $\mathrm{CC}$ rate $\left(7 \%{ }^{\circ} \mathrm{C}^{-1}\right)$ to a super-CC rate $\left(14 \%{ }^{\circ} \mathrm{C}^{-1}\right.$; e.g. Lenderink and Van Meijgaard, 2008, 2CC from hereafter).

An example of simulated rainfall fields for the four spatial rainfall scenarios, for the case with a temperature increase of $3^{\circ} \mathrm{C}$, is presented in Fig. 3. The effects of the changes in the spatial structure of the rainfall on the spatial correlation of the field are shown in Fig. 4.
In the second stage, the multiple stochastic realizations of design storms that were simulated for each of the 16 different scenarios and for the $2 \mathrm{CC}$ experiment were fed into a landscape evolution model (Sect. 2.3) to simulate the hydromorphological response, i.e. streamflow and sediment transport (Fig. 2). The sensitivity of the response to the changes in rainfall spatial properties was finally analysed.

\subsection{Space-time stochastic rainfall generator model}

Gridded stochastic rainfall generator models can be used to generate multiple realizations of a given (design) storm (McRobie et al., 2013; Paschalis et al., 2014; Peleg et al., 2018b; Shah et al., 1996a, b). The realizations preserve the temporal evolution of the mean areal rainfall over the domain, but they differ in how the rainfall intensities are distributed in space within the domain. Here a simplified version of the STREAP (Space-Time Realizations of Areal Precipitation) rainfall generator model was used for generating highresolution space-time rainfall fields (Paschalis et al., 2013). STREAP is based on previous space-time rainfall generators (Bell, 1987; Kundu and Bell, 2003; Pegram and Clothier, 2001a, b) and was recently further developed by Peleg et al. (2017b). The model simulates rainfall fields in three steps: (i) the length of the storms and the intra-storm periods are generated, (ii) the temporal evolution of the mean areal intensity over the domain and the fraction of wet area are simulated, and (iii) these time series are translated into intermittent space-time rainfall fields. As the design storm used in this study is predefined, only step (iii) is required in this study. Several modifications to this step were required in order to tailor the spatial structure of the rainfall fields to follow prescribed changes in both the peak and areal rainfall with temperature. The STREAP model is discussed in detail by Paschalis et al. (2013) and here only a brief description of step (iii) and specific modifications used in this case study are presented.

The intermittent rainfall field is simulated as a probability transformation of an isotropic Gaussian random field that is computed using the fast Fourier transform method. As in previous studies, we assume that rainfall intensity is spatially distributed following a log-normal distribution (e.g. Paschalis et al., 2013, 2014; Peleg et al., 2017b, 2018b, 2019). A log-normal function is therefore applied to convert the isotropic Gaussian field to the intermittent rainfall field. The information needed for this transformation is the mean areal rainfall over the domain (abbreviated hereafter as IMF, following the notations of Pegram and Clothier, 2001a) and the rainfall coefficient of variation $\left(\mathrm{CV}_{\mathrm{r}}\right)$ in space, which is a model parameter. Assuming that the rainfall covers the entire domain (i.e. the wet area ratio WAR is equal to 1), the intermittent rainfall fields are expressed as the following (see Paschalis et al., 2013 for details):

$R(x, y, t)=\mathrm{LN}^{-1}\left(U[G(x, y, t)], \mu_{\mathrm{r}}, \sigma_{\mathrm{r}}\right)$, 

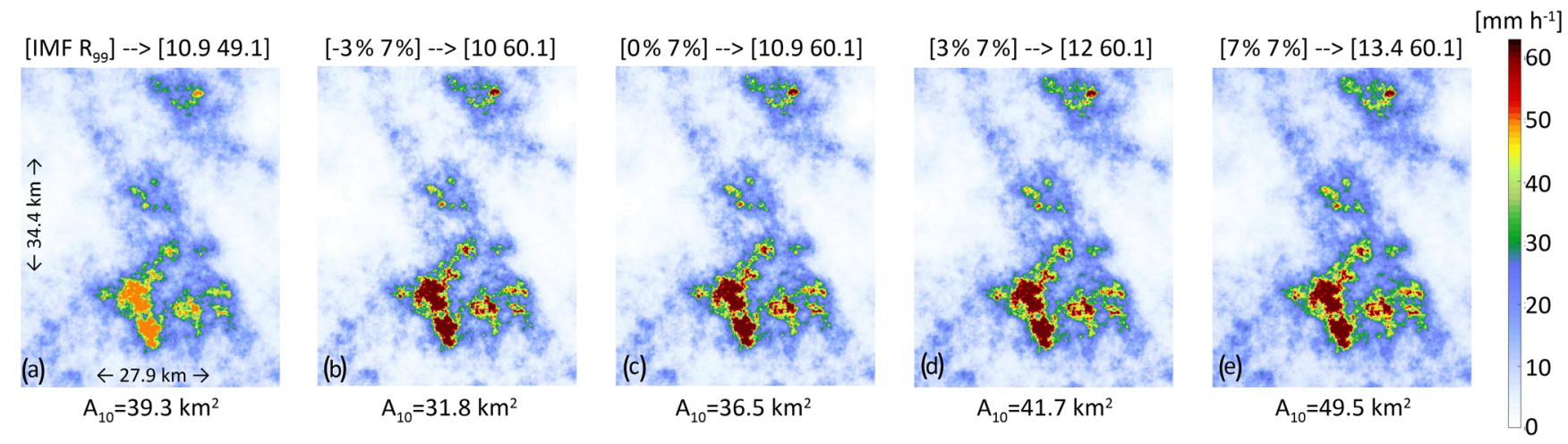

Figure 3. (a) An example of a stratiform simulated rainfall field for a given time step. (b-e) Plots of the rainfall field with four different "areal rainfall scenarios" (Table 1) and for a specific "temperature scenario" of $\Delta T=3{ }^{\circ} \mathrm{C}$. IMF refers to changes in the mean areal rainfall $\left(\%{ }^{\circ} \mathrm{C}^{-1}\right)$ and $R_{99}$ refers to changes in the peak rainfall intensity $\left(\%{ }^{\circ} \mathrm{C}^{-1}\right)$ in comparison to $(\mathbf{a})$; the absolute values of mean areal rainfall and peak rainfall intensity are given in parentheses $\left(\mathrm{mm} \mathrm{h}^{-1}\right) . A_{10}$ refers to the total area $\left(\mathrm{km}^{2}\right)$ above a rain intensity threshold of $10 \mathrm{~mm} \mathrm{~h}$.

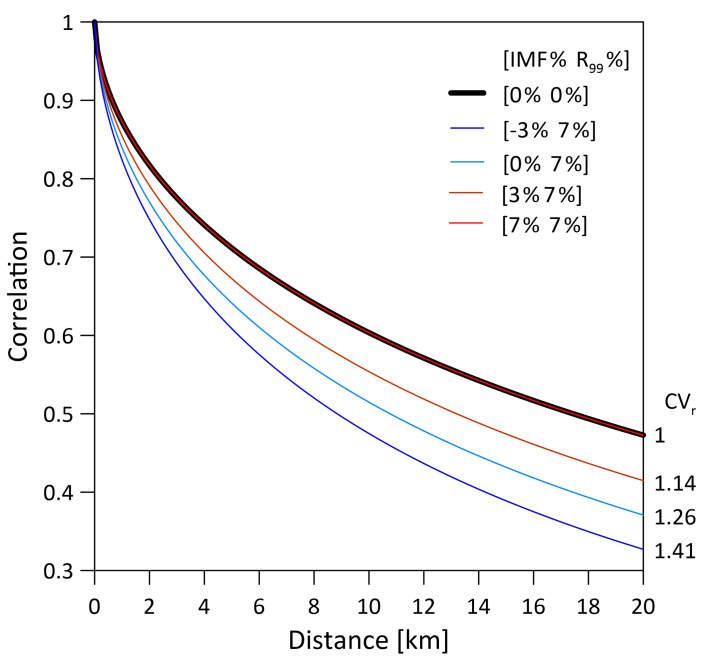

Figure 4. Spatial correlation of the rainfall fields that are presented in Fig. 3 for the specific case of $\Delta T=3^{\circ} \mathrm{C}$. The correlation is computed on the spectral densities of the fields following Peleg et al. (2019) and for each case the spatial coefficient of variation of the field $\mathrm{CV}_{\mathrm{r}}$ is given. IMF refers to changes in the mean areal rainfall $\left(\%{ }^{\circ} \mathrm{C}^{-1}\right)$ and $R_{99}$ refers to changes in the peak rainfall intensity $\left(\%{ }^{\circ} \mathrm{C}^{-1}\right)$.

where $R(x, y, t)$ is the rainfall intensity in space and time, $\mathrm{LN}^{-1}$ is the inverse cumulative log-normal distribution, and $U[G(x, y, t)]$ represents the percentiles in space and time of the latent isotropic Gaussian field. The parameters of the lognormal distribution, $\mu_{\mathrm{r}}$ and $\sigma_{\mathrm{r}}$, are expressed as

$\mu_{\mathrm{r}}=\log \left(\frac{\mathrm{IMF}(t)}{\sqrt{\mathrm{CV}_{\mathrm{r}}^{2}+1}}\right)$

and

$\sigma_{\mathrm{r}}=\sqrt{\log \left(\mathrm{CV}_{\mathrm{r}}^{2}+1\right)}$
The peak rainfall intensity at the grid scale is defined as the inverse log-normal of the 99th percentile, notated as $R_{99}$ and expressed as

$$
R_{99}(t)=e^{\log \left(\frac{\mathrm{IMF}(t)}{\sqrt{\mathrm{CV}_{\mathrm{r}}^{2}+1}}\right)+\sqrt{\log \left(\mathrm{CV}_{\mathrm{r}}^{2}+1\right)}\left[\sqrt{2} \operatorname{erf}^{-1}\left(2 \times 0.99^{-1}\right)\right]} .
$$

Equation (4) can be simplified to find a unique relation between the mean areal rainfall intensity (IMF) and the peak rainfall intensity at each time step:

$$
\log \left(\frac{R_{99}(t)}{\operatorname{IMF}(t)}\right)=2.3263 \sqrt{\log \left(\mathrm{CV}_{\mathrm{r}}^{2}+1\right)}-\log \left(\sqrt{\mathrm{CV}_{\mathrm{r}}^{2}+1}\right) .
$$

The rainfall spatial coefficient of variation is a model parameter that changes depending on the scenarios. If, for example, the $\mathrm{CV}_{\mathrm{r}}$ value for the reference simulation (i.e. $\Delta T=0{ }^{\circ} \mathrm{C}$ ) is equal to 1 , the $\mathrm{CV}_{\mathrm{r}}$ values will increase with an increasing difference between the scaling of the peak rainfall intensity and the areal rainfall. Convective and stratiform rainfall types have different reference values of $\mathrm{CVr}$. An example of how $\mathrm{CV}_{\mathrm{r}}$ changes as a function of the scaling of the peak rainfall and the areal rainfall intensities is presented in Fig. 4.

\subsection{Hydro-morphological model}

The hydrological and geomorphic response to rainfall is explored using a landscape evolution model (LEM; see review paper by Tucker and Hancock, 2010). The CAESAR (Coulthard et al., 2002) and CAESAR-Lisflood models (Coulthard et al., 2013) are grid-based LEMs that have been widely used to simulate morphodynamic changes from short temporal $(<1$ year or event based) and small spatial $\left(<1 \mathrm{~km}^{2}\right)$ scales (Coulthard et al., 2012a; Hoober et al., 2017) to long temporal $\left(>10^{4}\right.$ year) and large spatial $\left(10^{3} \mathrm{~km}^{2}\right)$ scales (Coulthard and Van De Wiel, 2017; Hancock et al., 
2010, 2015). Both models were used in the past to explore hydro-morphologic sensitivity to climate change and rainfall temporal variability (Coulthard et al., 2012b; Hancock, 2009, 2012; Hancock and Coulthard, 2012; Hoober et al., 2017). Recent versions of the CAESAR-Lisflood model have the ability to use gridded rainfall as an input (Coulthard and Skinner, 2016; Skinner et al., 2020), which is an essential ability for this study. This feature is lacking in many other LEMs. Surface runoff in the model is computed using the TOPMODEL hydrological model (Beven and Kirkby, 1979) and is routed downstream using the LISFLOOD-FP model (Bates et al., 2010), which generates flow depths and velocities. Fluvial erosion can be simulated using either Wilcock and Crowe, Einstein, or Meyer-Peter-Muller equations, moving sediment that is stored in an active-layer system that can handle up to nine grain sizes. Lateral erosion, slope processes, soil development, and interaction with vegetation are also simulated by the model. Version " $1.9 \mathrm{~h}$ " of the model was used in this study, and no modifications were made to the source code. For further details on the model, the reader is referred to Coulthard et al. (2013).

\section{Study catchment}

A medium size catchment (i.e. of the order of $10^{2}-10^{3} \mathrm{~km}^{2}$ ) is the most suitable case study for the designed numerical experiment. This can be either a synthetic or a real catchment. There are advantages to using a synthetic domain where the effects of different catchment properties (e.g. area, aspect) can be separated and individually examined (e.g. Mastrotheodoros et al., 2019). However, the main benefit of using a real catchment is that the LEM outputs can be validated against observations, in order to evaluate the model suitability in simulating the hydro-morphological response. In this study, we calibrated the model in a real catchment with observed data for a single large streamflow event where substantial sediment transport took place. The complexity of the simulation was reduced in order to eliminate possible effects of other variables besides rainfall (such as vegetation-erosion interactions) on the sensitivity of the hydro-morphological response. The model parameterization is discussed in Sect. 3.2.

The study was conducted in the Kleine Emme catchment (Fig. 5), located in central Switzerland $\left(47^{\circ} \mathrm{N}, 8^{\circ} \mathrm{E}\right)$. There are several reasons for the selection of this catchment: (i) intense convective rainfall events are common over the region during summer, and rainfall is associated with high spacetime variability (Isotta et al., 2014; Molnar et al., 2015; Panziera et al., 2018); (ii) the catchment is well monitored in terms of rainfall and streamflow, including the extreme rainfall and flood event that occurred in August 2005 with an estimated return period exceeding 100 years (Beniston, 2006; Jaeggi, 2008; Rickenmann et al., 2016; Rickenmann and Koschni, 2010); (iii) the hydrology and geomorphology

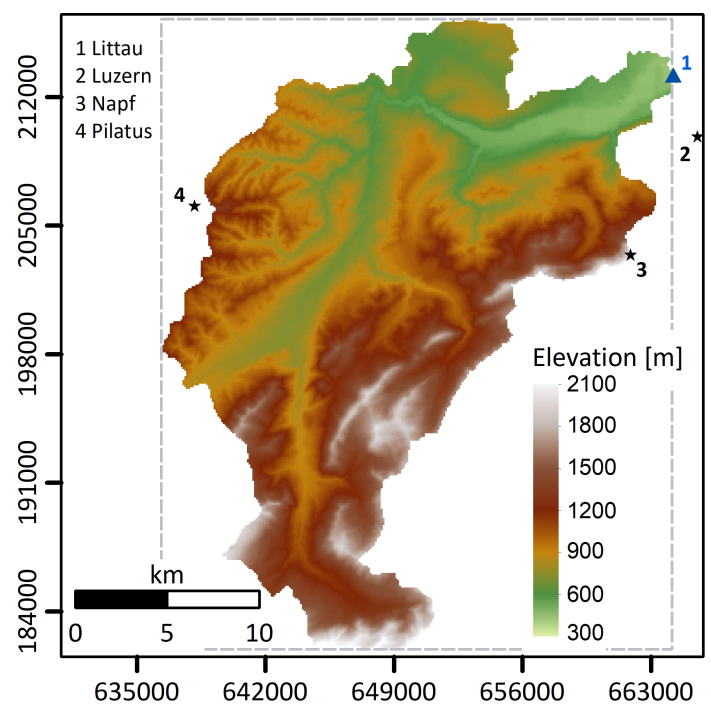

Figure 5. Topographic map of the Kleine Emme catchment. The blue triangle marks the location of the hydrometric station, and the black stars mark the locations of the meteorological stations that were used in this study. The dashed grey line represents the domain with simulated rainfall. Coordinates are in the Swiss reference system CH1903 (metres).

were successfully explored using numerical models for this catchment in the past (e.g. Battista et al., 2019; Heimann et al., 2015; Paschalis et al., 2014); (iv) the streamflow is close to natural conditions (i.e. without irrigation or hydropower uses), and the catchment is glacier free; and (v) the catchment is representative in terms of topographic (area of $477 \mathrm{~km}^{2}$, elevation range between 430 and $2300 \mathrm{~m}$ above sea level), hydrological, and geomorphological features of a typical Alpine catchment.

\subsection{Data}

We set the numerical models to simulate the impacts of a heavy rainfall event that is similar to the event that occurred in August 2005 (data for the period between 14 and 28 August were used). Rainfall data were gathered from the Swiss Federal Office for Meteorology and Climatology (MeteoSwiss) from two different products. Rainfall records at $10 \mathrm{~min}$ temporal resolution were obtained from three MeteoSwiss - SwissMetNet - ground stations surrounding the catchment (Fig. 5). Mean areal rainfall over the domain at 10 min was computed by averaging rainfall from the three locations. It was then temporally downscaled to $5 \mathrm{~min}$ resolution using linear interpolation. We assume that by using the data from these three stations, the temporal dynamics of the mean areal rainfall over the catchment is adequately represented (i.e. the timing of the storm is preserved). However, the mean areal rainfall intensities might not be representative for the entire catchment as the three meteorological stations are located in the northern part of the catchment (Fig. 5). 


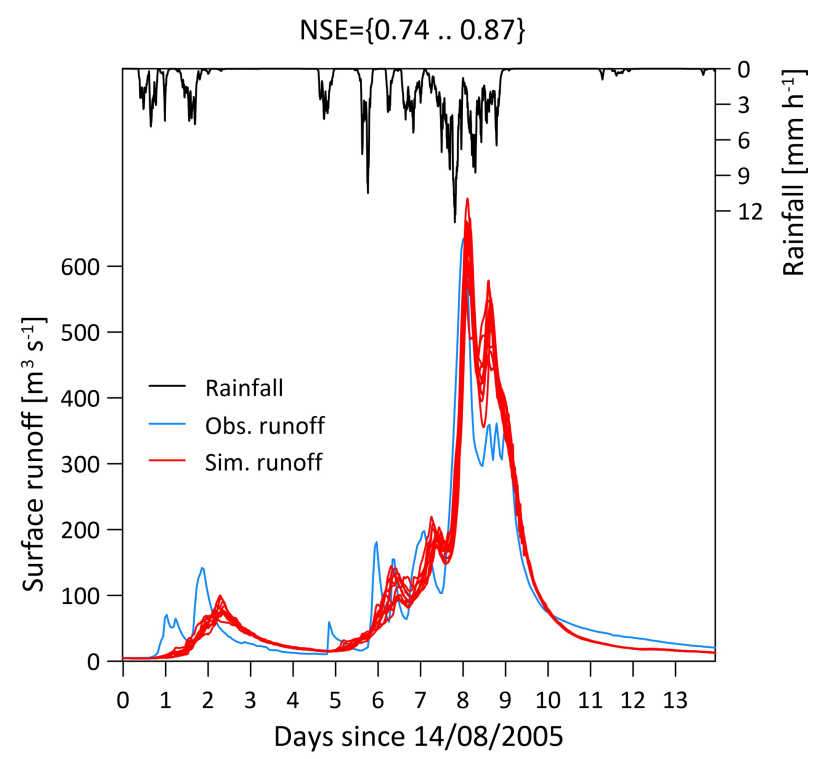

Figure 6. Illustration of the heavy rainfall event of August 2005 in the Kleine Emme catchment. The black line represents the mean areal rainfall over the catchment. The blue and red lines represent the observed and simulated hydrographs, respectively, at the outlet of the catchment. The 10 simulated lines are a result of the stochastic downscaling of the areal rainfall to a finer $(100 \mathrm{~m})$ spatial resolution using the rainfall generator model and its range represents the sensitivity of the hydrological response to the spatial rainfall variability.

Therefore, the rainfall amounts were corrected using data from gridded $1 \mathrm{~km}$ daily rainfall estimates that were derived from the MeteoSwiss product RhiresD (MeteoSwiss, 2016; Schwarb, 2000) that covers the entire catchment. For each day, the mean areal rainfall over the catchment was computed from the RhiresD product. The 5 min rainfall intensities were aggregated to the daily scale, compared with the daily RhiresD estimates, and corrected using a multiplicative factor. The final time series of the mean areal rainfall for the observed storm in August 2005 is presented in Fig. 6.

Hourly streamflow data were supplied by the Swiss Federal Office for the Environment for the Emmen station located at the outlet of the catchment (Fig. 5). Estimates of the sediment yield, grain size distribution, and the geomorphologic response to heavy rainfall events for the Kleine Emme, and for nearby catchments that are representative of the study area, were obtained from multiple sources (Bezzola and Hegg, 2008; Heimann et al., 2015; Rickenmann et al., 2008, 2016; Rickenmann and Koschni, 2010; Rickenmann and McArdell, 2007; Steeb et al., 2017). The digital elevation map (Fig. 5) and bedrock map (Supplement Fig. S1) were supplied by the Swiss Federal Office of Topography at $25 \mathrm{~m}$ resolution and were upscaled to $100 \mathrm{~m}$ resolution, which was the resolution used for model simulations. The surface roughness map (Fig. S2) at $100 \mathrm{~m}$ resolution was prepared based on a land use map that was obtained from the
Table 2. Parameters of the stochastic rainfall generator model.

\begin{tabular}{llr}
\hline Parameter & Units & Value \\
\hline Wet area ratio & - & 1 \\
Correlation length & $\mathrm{km}$ & 30 \\
Storm velocity & $\mathrm{km} \mathrm{h}^{-1}$ & 15 \\
Storm direction & ${ }^{\circ}$ from north & 90 \\
Coefficient of variation & - & 1 \\
of spatial rainfall & & \\
\hline
\end{tabular}

Swiss Federal Statistical Office following the classification suggested by Te Chow (1959).

\subsection{Setup of the rainfall generator model}

The parameters of the rainfall generator model (Table 2) were not calibrated to reproduce the statistics of a specific heavy rainfall event that was observed over the catchment but to simulate realistic space-time structure of rainfall fields over the Alpine region. The rainfall fields are simulated to move with a constant speed and direction as the hydrological response is sensitive to these parameters (Paschalis et al., 2014; Yakir and Morin, 2011). The parameters for the correlation length and storm velocity and direction follow reference values that were found by analysing rainfall fields obtained from a weather radar system in nearby Alpine catchments (Peleg et al., 2017a, b, 2019). The $\mathrm{CV}_{\mathrm{r}}$ parameter was set to be equal to 1 for the simulations of the real storm and for the simulation of the basic design stratiform storm (for $\Delta T=0$ ), and it was changed according to the different scaling scenarios (see Sect. 2.2 and Fig. 4). The wet area ratio is assumed equal to 1 for all simulations, as almost the entire catchment is covered with rainfall during heavy rainfall events (Paschalis et al., 2014).

The rainfall generator model is used to downscale the rainfall from its average value over the domain (i.e. mean areal rainfall) to a spatial rainfall field containing $344 \times 279$ grid cells at a fine resolution of $100 \mathrm{~m}$ in space (see example in Fig. 3). Over the domain, the generated rainfall fields preserve the value of the mean areal rainfall at each time step exactly. As the catchment is smaller than the domain extent, the areal rainfall amount computed over the catchment is likely to be a bit smaller too and not exactly equal in the various stochastic realizations. Note that the spatial rainfall scenarios refer to the changes in the areal rainfall for the entire domain extent. For each of the storms that were downscaled (the "real" storm of August 2005 and the different scenarios of the design storm), an ensemble of 10 realizations was stochastically generated in order to account for the natural spatial variability of the rainfall.

A design storm capable of triggering significant streamflow, erosion, and sediment transport over the catchment is required for the numerical experiment. Therefore, the storm was designed for a long duration of $24 \mathrm{~h}$, corresponding to 
the 90th percentile of storm durations for this catchment (Paschalis et al., 2014), and to reach a mean areal rainfall maximum of $10 \mathrm{~mm} \mathrm{~h}^{-1}$, which is slightly lower than the mean areal rainfall maximum that is reported for the August 2005 heavy rainfall event (between $13 \mathrm{~mm} \mathrm{~h}^{-1}$ as computed here and $14 \mathrm{~mm} \mathrm{~h}^{-1}$ as reported by Rickenmann and Koschni (2010) and by Steeb et al. (2017)) but still higher than the estimated value for a 10 -year return period (Paschalis et al., 2014).

Two types of rainfall, stratiform and convective, that have different spatial characteristics were examined, and they are both common in the Alpine region (Gaál et al., 2014). In general, stratiform rainfall is characterized with lower rainfall peaks and is more homogenous in space in comparison to convective rainfall (Benoit et al., 2018b; Panziera et al., $2015,2018)$. For the initial setting $(\Delta T=0)$ of the stratiform rainfall type, the rainfall peak at the grid scale $(100 \mathrm{~m}$ and $5 \mathrm{~min}$ ) was set to $49 \mathrm{~mm} \mathrm{~h}^{-1}$ - a rainfall peak that is estimated to be around the 2-year return period when comparing to MeteoSwiss stations in the region (e.g. the peak rainfall in Pilatus station for 2-year return period and 10 min duration is $54 \mathrm{~mm} \mathrm{~h}^{-1}$ ). In addition, a $\mathrm{CV}_{\mathrm{r}}$ value of 1 (rather homogenous rainfall field) was set. For the initial setting of the convective rainfall type, the rainfall peak at the grid scale was set to $120 \mathrm{~mm} \mathrm{~h}^{-1}$ (corresponding to 30 -year return period) and a $\mathrm{CV}_{\mathrm{r}}$ value of 3.85 was set, corresponding to a strongly nonhomogenous field typical of "convective cell formation".

\subsection{Setup of the LEM}

To reduce the complexity of the CAESAR-Lisflood model, several features were not used, such as lateral erosion (Van De Wiel et al., 2007) and vegetation effects on erosion (Hancock et al., 2015). The parameters of the CAESAR-Lisflood model (Table 3) were calibrated based on the August 2005 heavy rainfall event (Fig. 6). The model was used in catchment (basin) mode (Coulthard et al., 2013) using the Einstein (Einstein, 1950) formulation to compute sediment transport. The gridded rainfall realizations that were simulated by the rainfall generator were used as inputs into the model (as in Coulthard and Skinner, 2016; Skinner et al., 2020) and the model was set for the same spatial $(100 \mathrm{~m})$ and temporal (maximum dynamic time step of $5 \mathrm{~min}$ ) resolution as the rainfall fields. The model parameters are the same for all grid cells in the domain, except for the Manning coefficient values, which are spatially distributed (Fig. S2). Evaporation rate (Fatichi et al., 2015), and the values of grain size distribution and proportion (Rickenmann and McArdell, 2007), follows estimates and observations from nearby Alpine areas.

The hydrological TOPMODEL parameter " $m$ " (Beven and Kirkby, 1979) and the Courant number (Bates et al., 2010) were calibrated by finding the optimal fit between the simulated $14 \mathrm{~d}$ long hydrographs and the observed hydrograph (Fig. 6). The model was first run for a spin-up period of 1 year
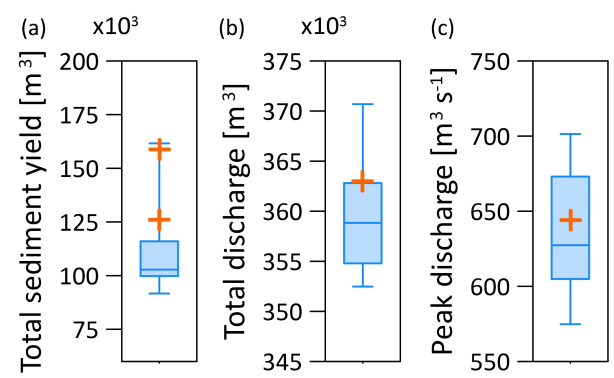

Figure 7. Box plots showing the median (horizontal line), 25th75th percentile range (shaded area), and maximum and minimum range (bounded with lines) of the total sediment yield (a), total streamflow volume (b), and peak streamflow (c) from the 10 downscaled spatial rainfall realizations for the heavy rainfall event of $\mathrm{Au}$ gust 2005. The orange "+" symbols represent the observed data for the total and peak streamflow and the estimated range of the total sediment yield.

to eliminate sharp gradient changes in the elevation and to redistribute the grain size distributions along the channels from the initial global setup described in Table 3. The calibration resulted in model efficiency (Nash and Sutcliffe, 1970) ranging between 0.74 and 0.87 as a result of different stochastic rainfall fields. The model also simulates well the total streamflow volume and peak streamflow, as both observed points fall within the 25 th -75 th percentile range of the 10 simulated realizations (Fig. 7).

The impacts of the changes in the spatial structure of heavy rainfall are expressed on bed load and suspended sediment load. For the August 2005 event, the volume of the sediment transport at the outlet of the catchment (minus the observed volume estimated for the lateral erosion that is not simulated by the model) was estimated between $125000 \mathrm{~m}^{3}$ (Bezzola and Hegg, 2008) and $160000 \mathrm{~m}^{3}$ (Rickenmann et al., 2016; Rickenmann and Koschni, 2010). Most simulated realizations underestimate the reported volumes (25th-75th percentile range, Fig. 7), yet two of the realizations do fall within this range (simulating 128620 and $161600 \mathrm{~m}^{3}$ of sediment yield).

Each individual simulation of the design storm experiment runs for an $8 \mathrm{~d}$ period. The first $4 \mathrm{~d}$ are used as a spin-up period to stabilize the streamflow at the outlet of the catchment for a baseflow of $10 \mathrm{~m}^{3} \mathrm{~s}^{-1}$, which is similar to the observed value. Consequently, model output analysis and performance metrics for these simulations were computed after day 4 .

\section{Results}

The sensitivity of the hydro-morphological response to the changes in rainfall spatial structure was examined in terms of peak streamflow and sediment yield for the total volumes of streamflow and sediment yield and for the inundated area and the area subjected to erosion or deposition. For each of these components, the mean value from the 10 simulated re- 
Table 3. Parameters of the CAESAR-Lisflood model.

\begin{tabular}{lll}
\hline Parameter & Units & Values \\
\hline Grain sizes & $\mathrm{m}$ & $0.00035,0.003,0.016,0.04,0.125,0.2$ \\
Grain size proportions (sum to 1) & - & $0.1,0.2,0.2,0.2,0.2,0.1$ \\
Suspended sediment fall velocity & $\mathrm{m} \mathrm{s}^{-1}$ & 0.045 \\
Sediment transport law & - & Einstein \\
Max erode limit & $\mathrm{m}$ & 0.005 \\
Active layer thickness & $\mathrm{m}$ & 0.1 \\
TOPMODEL "m" value & - & 0.01 \\
Water depth threshold for erosion & $\mathrm{m}$ & 0.01 \\
Courant number & - & 0.3 \\
Manning's coefficient & - & $0.01-0.2$ (distributed, see Fig. S2) \\
\hline
\end{tabular}

alizations was computed for each of the scenarios. Results are presented first for stratiform rainfall, then for convective rainfall, and followed by a summary of the overall findings.

\subsection{Stratiform rainfall type}

Peak streamflow and sediment yield - as expected - are predicted to enhance (reduce) with increasing (decreasing) rainfall amounts; however, the peaks were found to be mainly sensitive to the changes in the mean areal rainfall, since changing rainfall peak intensity only did not affect streamflow considerably. For example, examining the results for $\Delta T=4{ }^{\circ} \mathrm{C}$ in Fig. 8 , an increase of the mean areal rainfall by $7 \%{ }^{\circ} \mathrm{C}^{-1}$ resulted in an increase in peak streamflow by $62 \%$, an increase of the mean areal rainfall at a rate of $3 \%{ }^{\circ} \mathrm{C}^{-1}$ resulted in an increase in peak streamflow by $25 \%$, and a decrease in the mean areal rainfall at a rate of $-3 \%{ }^{\circ} \mathrm{C}^{-1}$ resulted in a decrease in peak streamflow by $-18 \%$. The peak sediment yield also showed higher sensitivity to changes in mean areal rainfall (Fig. 8, changes to the symbol sizes). For example, for $\Delta T=4{ }^{\circ} \mathrm{C}$, an increase of the mean areal rainfall by $7 \%{ }^{\circ} \mathrm{C}^{-1}$ and $3 \%{ }^{\circ} \mathrm{C}^{-1}$ resulted in an increase of $210 \%$ and $84 \%$, respectively, in the peak sediment yield, and a decrease in the mean areal rainfall at a rate of $-3 \%{ }^{\circ} \mathrm{C}^{-1}$ resulted in a decrease in sediment yield peak by $-31 \%$, underlining how non-linearities in sediment transport are much stronger than for discharge.

Focusing on the results where the peak rainfall intensity at the grid scale is intensifying by $7 \%{ }^{\circ} \mathrm{C}^{-1}$ but the mean areal rainfall remains unchanged (Fig. 8, orange symbols) reveals different sensitivities for the peak streamflow and peak sediment yield. Although the peak rainfall at the grid scale intensified, peak streamflow is hardly affected; the maximum enhancement is $2 \%$ for the $\Delta T=4^{\circ} \mathrm{C}$ scenario, which is almost negligible. However, the intensification of the peak rainfall at the grid scale resulted in a considerable enhancement of the peak sediment yield of $4 \%$ for $\Delta T=1{ }^{\circ} \mathrm{C}$, $8 \%$ for $\Delta T=2{ }^{\circ} \mathrm{C}, 11.8 \%$ for $\Delta T=3{ }^{\circ} \mathrm{C}$, and $16.4 \%$ for $\Delta T=4{ }^{\circ} \mathrm{C}$ (Fig. 8).

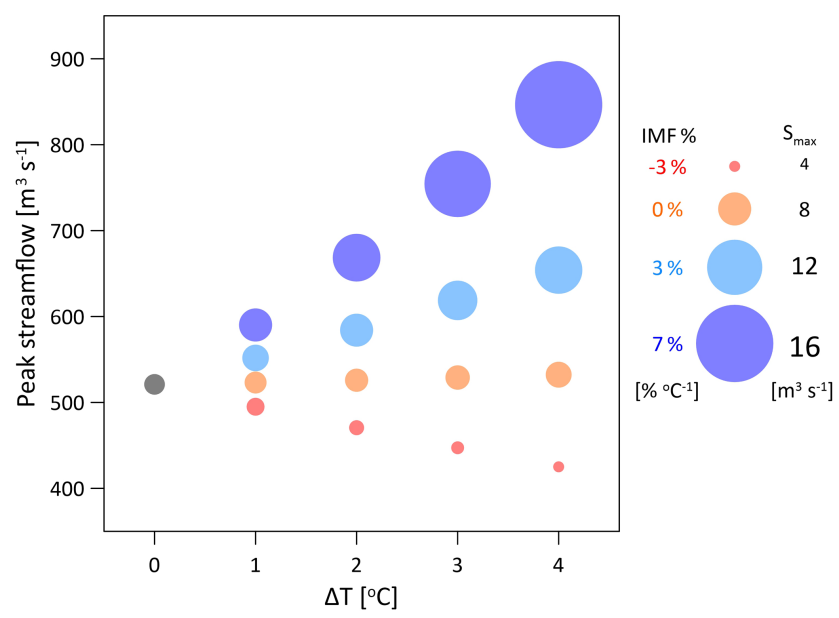

Figure 8. Response of the peak streamflow ( $y$ axis) and peak sediment yield (symbol size, $S_{\max }$ ) at the outlet of the catchment to changes in the rainfall spatial structure with temperature for stratiform rainfall type. Peak rainfall intensity increases by $7 \%{ }^{\circ} \mathrm{C}^{-1}$ for all points. Different colours represent a mean areal rainfall intensity change: decrease of $-3 \%{ }^{\circ} \mathrm{C}^{-1}$ (red), not changing (orange), increase of $3 \%{ }^{\circ} \mathrm{C}^{-1}$ (blue), and increase of $7 \%{ }^{\circ} \mathrm{C}^{-1}$ (dark blue). Reference (base scenario) for the sensitivity is the single point at $\Delta T=0$ (grey).

Similar sensitivities were found when examining the effects of the intensification of the peak rainfall intensity at the grid scale on total streamflow and sediment yield, assuming no changes to the mean areal rainfall (case 2). While total streamflow changed by less than $1 \%$ for the different temperature scenarios, total sediment yields increased by $2 \%$, $4 \%, 7 \%$, and $9 \%$ for the $\Delta T=1$ to $4{ }^{\circ} \mathrm{C}$ scenarios, respectively. However, modifying the mean areal rainfall, even by simply applying $\pm 3 \%{ }^{\circ} \mathrm{C}^{-1}$, resulted in a change to the total sediment yields higher than $10 \%$ (Fig. 9).

The geomorphic multiplier implies a non-linear relation between total streamflow and total sediment yield (Coulthard et al., 2012b). Plotting these two quantities against each other (Fig. 9), using information from all the scenarios, the sensi- 


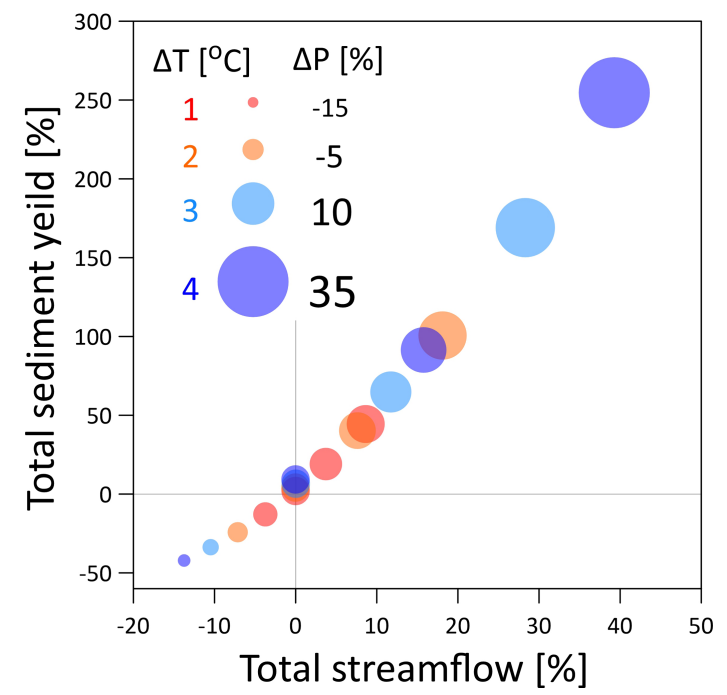

Figure 9. Changes in the total sediment yield ( $y$ axis) as a function of the changes in total streamflow ( $x$ axis) in relation to the changes in total rainfall amounts (symbol size, $\Delta P$ for stratiform rainfall type). The relevant temperature scenario $(\Delta T)$ is expressed by the colour of the symbols $\left(1^{\circ} \mathrm{C}-\right.$ red, $2{ }^{\circ} \mathrm{C}$ - orange, $3{ }^{\circ} \mathrm{C}-$ blue, and $4{ }^{\circ} \mathrm{C}$ - dark blue). The reference to compute the changes is the total streamflow and sediment transport of the base scenario (at $\Delta T=0$ ).

tivity of the geomorphic multiplier to changes in the rainfall spatial structure can be shown. The relation between the simulated total sediment yield and total streamflow were found to follow a power law once fitted to the actual simulated values of the total streamflow and sediment yield $\left(R^{2}=0.99\right.$, not shown), which is closely correlated to the changes in total rainfall amounts ( $\Delta P$, symbol size). Most points fall directly along the fitted line - which implies that the total streamflow and total sediment yield are mainly sensitive to changes in the total rainfall volume. Points that deviate from the fitted line, e.g. the scatter of dots along the $y$ axis close to the $0 \%$ change in total streamflow, have different spatial structures of rainfall. The sensitivity of the total sediment yield to changes in the rainfall spatial structure, due to the intensification of peak rainfall intensity or due to different rainfall spatial correlation structures is estimated to be of the order of $\pm 10 \%$ (of the reference total sediment yield).

The spatial sensitivity of the hydro-morphological response was lastly examined by means of two spatial indices: (i) the maximum inundated area for each realization, defined as the total area with water levels higher than $1 \mathrm{~cm}$, which represents the area of overland flow on hillslopes and flow in channels and (ii) the total area of erosion or deposition (active area from hereafter), defined by comparing the elevation map at the end of the realization to the pre-storm elevation map and summing the grid cells where net erosion or deposition occurred (i.e. grid cells with elevation difference greater than $1 \mathrm{~cm}$; see example in Fig. S3). Both the maximum inundated area and active area were found to react to the changes in mean areal rainfall intensity. An increase in areal rainfall amounts and in the area of heavy rainfall resulted in an increase in both the maximum inundated and active areas (IMF $\%=3 \%$ and $7 \%$, Fig. 10), while a decrease in areal rainfall amounts and in the area of heavy rainfall resulted in a decrease in both (IMF $\%=-3 \%$, Fig. 10). The maximum inundated area and active area has a different sensitivity to the intensification of peak rainfall intensity for the case when the mean areal rainfall remain unchanged (case 2, IMF $\%=0 \%$ ). In this case the maximum inundated area was found to slightly decrease from $54.5 \mathrm{~km}^{2}$ for $\Delta T=0^{\circ} \mathrm{C}$ to $54.3 \mathrm{~km}^{2}$ for $\Delta T=4{ }^{\circ} \mathrm{C}$ (Fig. 10a) - practically remaining unchanged (less than $1 \%$ change), while the active area was found to increase from $67.6 \mathrm{~km}^{2}$ for $\Delta T=0^{\circ} \mathrm{C}$ to $71 \mathrm{~km}^{2}$ $(+5 \%)$ for $\Delta T=4{ }^{\circ} \mathrm{C}$ (Fig. 10b).

\subsection{Convective rainfall type}

The hydro-morphological response driven by convective rainfall was compared to the response obtained with the stratiform rainfall experiment. Similar trends for the hydromorphological response were found for the two rainfall types; however, magnitudes were different for some of the examined components. Differences in the hydromorphological response for the $\Delta T=2{ }^{\circ} \mathrm{C}$ scenario between the two rainfall types were compared for cases 1 to 3 (Table 4). The hydro-morphological response for the scenario in which both the peak rainfall intensity and mean areal rainfall are intensifying (case 3) is similar for the two rainfall types (Table 4). For the case where the peak rainfall intensified while the mean areal rainfall intensity weakened (case 1), a more pronounced decrease (between the two rainfall types) in the peak streamflow, total sediment yield, and in the active area were found for the simulations with the stratiform rainfall type (Table 4). On the other hand, the decrease in the maximum inundated area and total streamflow were larger, and the response of the peak sediment yield had a different sign for the convective rainfall type (Table 4).

Differences in the hydro-morphological response were also found for case 2 (no change in areal rainfall, Table 4). While for the stratiform rainfall the peak streamflow remains unchanged and a small increase in the peak sediment yield was reported, for the convective rainfall both peaks considerably increased. The streamflow volume remains unchanged for both rainfall types, while the enhancement of the total sediment yield was found to be more pronounced for the convective rainfall type. As for the stratiform rainfall, the streamflow volume and total sediment yield simulated with the convective rainfall are related by a power law relation $\left(S=8.1 \times 10^{-17} Q^{3.7}\right.$ and $S=6.5 \times 10^{-13} Q^{3}$ for stratiform and convective rainfalls, respectively, where $S$ is total sediment yield and $Q$ is total discharge, $R^{2}=0.99$ for both cases). The difference in the exponential relations between the two rainfall types implies that the geomorphic multiplier, besides being dependent on the catchment characteristics and 

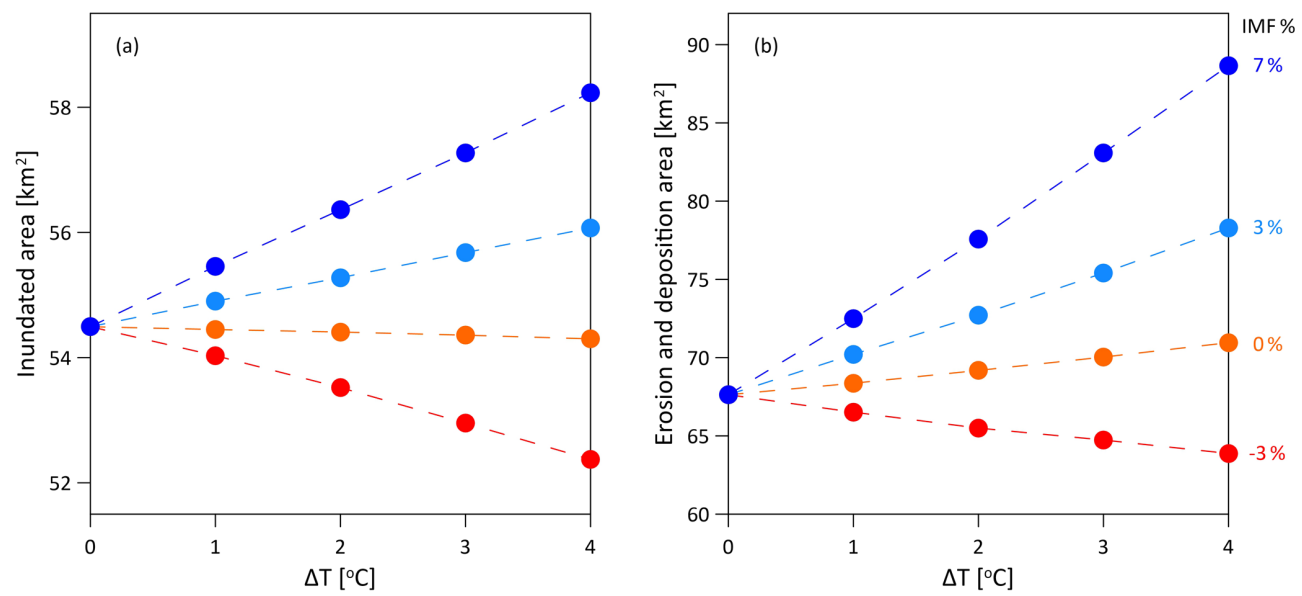

Figure 10. The sensitivity of the maximum inundated area (a) and the active erosion plus deposition area (b) to changes in the rainfall spatial structure with temperature for stratiform rainfall type. Peak rainfall intensity increases by $7 \%{ }^{\circ} \mathrm{C}^{-1}$ for all points. Different colours represent mean areal rainfall intensity decrease of $-3 \%{ }^{\circ} \mathrm{C}^{-1}$ (red), not changing (orange), increases of $3 \%{ }^{\circ} \mathrm{C}^{-1}$ (blue), and increases of $7 \%{ }^{\circ} \mathrm{C}^{-1}$ (dark blue). Reference (base scenario) for the sensitivity is the point at $\Delta T=0$.

Table 4. The hydro-morphological response produced by stratiform and convective rainfall types for the $\Delta T=2^{\circ} \mathrm{C}$ scenario in comparison to the reference scenario $\left(\Delta T=0{ }^{\circ} \mathrm{C}\right)$.

\begin{tabular}{|c|c|c|c|c|c|c|c|c|}
\hline & \multicolumn{4}{|c|}{ Stratiform rainfall } & \multicolumn{4}{|c|}{ Convective rainfall } \\
\hline & Reference & Case 1 & Case 2 & Case 3 & Reference & Case 1 & Case 2 & Case 3 \\
\hline Peak streamflow & $521 \mathrm{~m}^{3} \mathrm{~s}^{-1}$ & $-9.6 \%$ & $0.9 \%$ & $12.1 \%$ & $583 \mathrm{~m}^{3} \mathrm{~s}^{-1}$ & $-5.4 \%$ & $3.9 \%$ & $13.9 \%$ \\
\hline Peak sediment yield & $5.7 \mathrm{~m}^{3} \mathrm{~s}^{-1}$ & $-17.8 \%$ & $8 \%$ & $38.9 \%$ & $11.2 \mathrm{~m}^{3} \mathrm{~s}^{-1}$ & $1.7 \%$ & $15.1 \%$ & $32 \%$ \\
\hline Total streamflow & $104035 \mathrm{~m}^{3}$ & $-7 \%$ & $0 \%$ & $8 \%$ & $103924 \mathrm{~m}^{3}$ & $-8 \%$ & $-1 \%$ & $7 \%$ \\
\hline Total sediment yield & $324 \mathrm{~m}^{3}$ & $-24 \%$ & $4 \%$ & $40 \%$ & $481 \mathrm{~m}^{3}$ & $-8 \%$ & $12 \%$ & $37.3 \%$ \\
\hline Maximum inundated area & $54.5 \mathrm{~km}^{2}$ & $-1.8 \%$ & $-0.2 \%$ & $1.4 \%$ & $52.9 \mathrm{~km}^{2}$ & $-5.7 \%$ & $-1.9 \%$ & $0.7 \%$ \\
\hline Area of erosion and deposition & $67.6 \mathrm{~km}^{2}$ & $-3.2 \%$ & $2.3 \%$ & $7.5 \%$ & $82.1 \mathrm{~km}^{2}$ & $-1 \%$ & $3 \%$ & $6.8 \%$ \\
\hline
\end{tabular}

sediment supply, depends to a certain extent on rainfall structure as well.

\subsection{Summary of the CC experiment}

A qualitative summary of the sensitivity of the hydromorphologic response to the two rainfall types is presented in Table 5.

The response of the hydrological component ranges from no response (stratiform rainfall) to low positive response (convective rainfall) for the case where intensification of the peak rainfall intensity at the grid scale is the only change considered (case 2), with a low (stratiform) to medium (convective) positive response for the geomorphological components. The response is markedly positive for an increase in the mean areal rainfall (case 3) for both rainfall types, with a medium enhancement of streamflow volume and peaks and high enhancement of sediment peak and total yield. The response for a decrease in the mean areal rainfall (case 1) is toward a decrease of the analysed variables, but differences can be observed for the two rainfall types. For strat- iform rainfall, both the hydrological and geomorphological variables showed a medium negative response, while for the convective rainfall a medium negative response was detected for the hydrological variables but a milder negative response was found for the geomorphological ones. Results demonstrated that the hydro-morphological response is sensitive to the rainfall spatial structure as conditioned on the rainfall type, even though rainfall volume remains the most important factor.

\subsection{CC experiment}

Enhancements in the peak streamflow and peak sediment yield were found when increasing the peak rainfall intensity with temperature using a $2 \mathrm{CC}$ scaling in the convective storm experiment while preserving the mean areal rainfall. For example, for $\Delta T=1{ }^{\circ} \mathrm{C}$, the peak streamflow moderately increased from $583 \mathrm{~m}^{3} \mathrm{~s}^{-1}$ (reference) to $593 \mathrm{~m}^{3} \mathrm{~s}^{-1}$ (CC) and $604 \mathrm{~m}^{3} \mathrm{~s}^{-1}$ (2CC), while the peak sediment yield increased from $11.2 \mathrm{~m}^{3} \mathrm{~s}^{-1}$ (reference) to $12 \mathrm{~m}^{3} \mathrm{~s}^{-1}$ (CC) and $12.8 \mathrm{~m}^{3} \mathrm{~s}^{-1}$ (2CC). In addition, a subtle decrease in the 
Table 5. A qualitative summary of the hydro-morphological response to the three main studied cases (Fig. 1) for the rainfall spatial structure corresponding to stratiform and convective types. For all three cases, the peak rainfall intensity at the grid scale intensifies. Case (1) total rainfall amount decreases, area of heavy rainfall decreases; case (2) total rainfall amount remains unchanged and area of heavy rainfall slightly decreases; case (3) total rainfall amount increases and area of heavy rainfall increases. The response varies between a strong negative response $(---)$, no change (o), and a strong positive response $(+++)$.

\begin{tabular}{lccc|ccc}
\hline & \multicolumn{3}{c|}{ Stratiform rainfall } & \multicolumn{3}{c}{ Convective rainfall } \\
\cline { 2 - 7 } & Case 1 & Case 2 & Case 3 & Case 1 & Case 2 & Case 3 \\
\hline Peak streamflow & -- & 0 & ++ & - & + & ++ \\
Peak sediment yield & -- & + & +++ & 0 & ++ & +++ \\
Total streamflow & -- & 0 & ++ & -- & 0 & ++ \\
Total sediment yield & -- & + & +++ & - & ++ & +++ \\
Inundated area & - & 0 & + & -- & 0 & + \\
Area of erosion and deposition & -- & + & +++ & - & + & +++ \\
\hline
\end{tabular}

streamflow volume and a considerable increase in the total sediment yield were observed, respectively reducing from $103924 \mathrm{~m}^{3}$ (reference) to $103326 \mathrm{~m}^{3}$ (2CC) and increasing from $481 \mathrm{~m}^{3}$ (reference) to $535 \mathrm{~m}^{3}$ (2CC). A decrease was found for the maximum inundated area, from $52.9 \mathrm{~km}^{2}$ (reference) to $51.9 \mathrm{~km}^{2}$ (2CC), while an increase was observed for the active area, from $82.1 \mathrm{~km}^{2}$ (reference) to $84.5 \mathrm{~km}^{2}$ (2CC).

\section{Discussion}

\subsection{Physical interpretation of the hydro-morphological responses}

As expected, intensification of the peak and mean areal rainfall lead to a higher streamflow peak because the total amount of rainfall considerably increases (Table 4, case 3). However, localized intensifications of the peak rainfall alone, without changes to the total rainfall amounts (case 2), do not necessarily enhance the peak streamflow as the intensification of the peak rainfall is associated with a decrease in the area of the heavy rainfall over the entire rainfall field to preserve the rainfall volume. Stratiform rainfall fields are characterized by relatively high spatial correlation in space that is not changing dramatically between the reference and design scenarios (e.g. Fig. 4). That means that the local intensification of heavy rainfall and decrease of the area of heavy rainfall over the rainfall fields results in minor changes to the volume of rainfall that is reaching the catchment at a given time, thus the peak streamflow remains largely unchanged (e.g. Bell and Moore, 2000; Gupta et al., 1996; Kalinga and Gan, 2006). However, for convective rainfall, the change in rainfall spatial structure is expressed by generating high-intensity convective features (Haerter, 2019; Haerter et al., 2017) that are contributing higher volumes of rainfall to specific parts of the catchment in shorter durations, resulting in an enhancement of runoff and peak streamflow (e.g. Morin et al., 2006; Peleg et al., 2015; Yakir and Morin, 2011). When the mean areal rainfall is decreasing but the peak rainfall is intensifying (Ta- ble 4, case 1), for both stratiform and convective rainfall we observed a decrease in the peak streamflow due to the lower rainfall volumes but such a decrease is much less pronounced for convective rainfall.

Unsurprisingly, the changes in streamflow volume are following the changes in the total rainfall volume, which are expressed by changes in mean areal rainfall (Table 4, cases 1 and 3). However, the streamflow volume is not sensitive to the intensification of the peak rainfall by itself (case 2), as negligible (less than $1 \%$ ) changes in streamflow volume were produced. Similarly, the maximum inundated area was found to be sensitive mainly to the changes in the mean areal rainfall and therefore rainfall volume. A larger decrease in the inundated area is observed for the convective rainfall in comparison to the stratiform rainfall (Table 4, case 1). This is related to the fact that intense convective rainfall features vary significantly in space and sometimes are not covering the entire catchment, in such a case not all tributaries are affected by the heavy rainfall (Goodrich et al., 1995; Lopes, 1996), and the total inundated area tends to decrease.

The geomorphological variables, peak and total sediment yield, and area of erosion or deposition were found to be more sensitive to changes in rainfall structure itself in comparison to the hydrological variables (Table 4). This is related to the geomorphic multiplier, i.e. the capacity of sediment transport to respond disproportionally to a change in the hydrological regime, and it is the outcome of processes, which are triggered only when certain thresholds are exceeded. The intensification of the peak rainfall intensity at the grid scale alone (case 2) explains part of the response, as higher rainfall rates are expected to enhance soil erosion (Nearing et al., 2004, 2005; Shen et al., 2016) and trigger more landslides and debris flows (Guzzetti et al., 2008; Iverson, 2000; Leonarduzzi et al., 2017). Although not explicitly exploring the geomorphological response at the storm scale, Coulthard et al. (2012b), Coulthard and Skinner (2016), and Deal et al. (2017) discussed already the role of local extreme rainfall intensity in enhancing erosion and accelerating landscape 
evolution. Adding to their conclusions, it is clear that the geomorphological response is sensitive to the rainfall type as intense convective rainfall features enhance the geomorphological response (Table 4, case 2).

\subsection{Implications for climate change impact studies}

Results imply that the hydro-morphological response of medium-sized catchments is influenced by changes in the rainfall spatial structure at small scale, and, due to abovementioned threshold effects, the geomorphological variables are more sensitive to changes in rainfall structure than the hydrological variables. Various representative cases of changes in rainfall spatial structure with increasing temperature were explored in order to study the sensitivity of the fluvial system to these changes. We note that the changes in rainfall structure can be more complex than schematized in this work. For example, Wasko et al. (2016) showed that the intensification of the peak rainfall is associated with a reduction in the area of the storm and with an intensification of the mean areal rainfall but at a lower rate than the intensification in the rainfall peak. Additionally, the relations between the rainfall spatial structure and temperatures were observed so far only in a few locations worldwide (Lochbihler et al., 2017; Peleg et al., 2018b; Wasko et al., 2016), and they remain unknown for most locations.

Representing spatial rainfall structures requires highresolution simulations. In hydrology, using gridded rainfall data for climate change impact studies is becoming common practice. In recent years, there has been an increase in the availability of distributed hydrological models (Fatichi et al., 2016; Paniconi and Putti, 2015), and they have been used in the context of climate impacts (e.g. Dams et al., 2015; Fatichi et al., 2015; Perra et al., 2018). However, this is much less the case for geomorphological impacts (e.g. Francipane et al., 2015; Pandey et al., 2016; Ramsankaran et al., 2013; $\mathrm{Zi}$ et al., 2016), where the added value of using high-resolution gridded rainfall data for climate change impact studies is still not widely explored (Li and Fang, 2016) and most LEMs do not receive distributed rainfall as input (Coulthard and Skinner, 2016; Tucker and Hancock, 2010). The risk of over-predicting the geomorphological response is significantly increased when using uniform rainfall instead of distributed rainfall. This was discussed by Coulthard and Skinner (2016) and here we demonstrate plausible consequences of global warming on the spatial rainfall structure and its potential impacts. Specifically, case 4 represents the situation where both peak rainfall intensity and mean areal intensity are assumed to intensify at the same rate, meaning that the rainfall amounts are increasing while the rainfall spatial structure remains largely unchanged. In the context of a climate change study, using case 4 would be equivalent to using the observed rainfall and increasing the rainfall amounts evenly over the catchment in response to climate change. The peaks of streamflow and sediment yield
(Fig. 8), streamflow volume and total sediment yield (Fig. 9), and inundated area and active area (Fig. 10) - all these quantities - will be over-predicted for such a case in comparison to other scenarios, where the areal and peak rainfall intensities, and thus the rainfall spatial structure, are changing at different rates. This also emphasizes the importance of using either high-resolution CPMs to simulate changes in the rainfall for the future climate or appropriate downscaling of the rainfall simulations from climate models. If downscaling is based on simple relationships between rainfall and temperature that are measured at the point scale (i.e. using ground stations), results must be analysed with care, as often these relationships are extrapolated to a much larger (catchment) scale (Dahm et al., 2019; Fadhel et al., 2018; Lenderink and Attema, 2015). A viable alternative is presented here. It is represented by space-time rainfall generators, which allow for downscaling of the rainfall to the required space-time resolution while maintaining realistic spatial characteristics of rainfall fields based on current observations at a point and weather radar scales and factors of change derived from climate models (e.g. Peleg et al., 2019).

\subsection{Generalization and limitations of the numerical experiment}

The presented study offers a quantification of the effects of different spatial structures of rainfall using 10 stochastic realizations and their effects on key hydro-morphological variables, but it also refers to a single design storm, a single catchment, and only one LEM. The design storm represents a realistic storm in terms of rainfall amount, but it is simplified in terms of the temporal evolution, which can affect the fluvial response (Istanbulluoglu and Bras, 2006; Tucker and Bras, 2000). Furthermore, the storm is advected with a fixed velocity and direction, and the rainfall is assumed to cover the entire catchment - assumptions that can affect the hydrograph peak, volume, and timing (Morin et al., 2006; Singh, 1997; Yakir and Morin, 2011). The LEM was used with a simplified setup that does not include vegetation-erosion interactions and lateral erosion; concurrently, the hydrological module is not representing all of the hydrological processes, such as changes in soil saturation and infiltration capacity, which can be important for precise estimation of the hydromorphological response (Coulthard et al., 2013; Paschalis et al., 2014; Tucker and Hancock, 2010). The TOPMODEL formulation of runoff production, controlled exclusively by the saturated area that is proportional to the rainfall volume, scales the streamflow volume almost linearly with the rainfall volume. Alternative representations of runoff production that are more realistic may provide a more pronounced non-linear response of the hydrology of the catchment and therefore emphasize the role of rainfall spatial variability. However, the LEM validation proved that the model simulates streamflow and sediment yield satisfactorily for the examined $15 \mathrm{~d}$ period, which generates confidence in the overall predictions. 
Even though we use a single catchment, the Kleine Emme catchment can be considered representative of an average Alpine catchment in terms of elevation, land use, and stream morphology, and the sensitivities of the hydro-morphological response to different spatial representations of heavy rainfall found in this study are likely indicative of the behaviour of other medium-sized mountainous catchments. Extrapolations for other climatic regions, rainfall regimes, and catchments with a different topography and geomorphology are instead highly speculative.

In this study, we considered sediment yield at the outlet of the catchment and the total area of erosion and deposition within the catchment as a representative function of the geomorphic change to rainfall structure. Internal geomorphological changes (see Skinner et al., 2018) can be explored and can be the subject of future work.

Finally, while we studied the small-scale spatial structure of rainfall, additional research is needed in order to understand the sensitivity of the catchment to the rainfall temporal structure at fine scale and its relative importance when compared to spatial structure in shaping the landscape over long (millennial) periods.

\section{Conclusions}

A numerical experiment was conducted to examine the sensitivity of the hydro-morphological response to changes in rainfall spatial structure, as plausibly modified by increasing temperatures for stratiform and convective rainfall types. Results demonstrated that hydrological and morphological related variables are sensitive to changes in the rainfall spatial structure, with a much higher sensitivity for the morphological components (e.g. peak sediment yield) in comparison to the hydrological components (e.g. peak streamflow). This is due to responses activated only when certain thresholds (rainfall intensity for runoff driven erosion, discharge for sediment transport) are exceeded (the geomorphic multiplier), while hydrological processes in this catchment are simulated to scale almost linearly with rainfall amount. Regardless of uncertainty, predicting changes in hydro-morphological response requires plausible scenarios of how both the peak rainfall intensity at small spatial scale and the mean areal rainfall of heavy storms are going to change in a different climate, as was done here. Neglecting changes in the rainfall spatial structure and assuming that the mean areal and peak rainfall intensities will follow a similar scaling with increasing temperatures may be misleading and lead to overprediction of the hydro-morphological response. This effect is likely to be more pronounced for convective rainfall that produces more localized runoff and erosion potential.

Code and data availability. All the data used in this study are freely available and can be collected from the relevant agencies that are mentioned in Sect. 3.1 and in the acknowledgements be- low. The MATLAB source code of the rainfall generator model (or the full version of the AWE-GEN-2d model) is available, upon request, from Nadav Peleg. Any element of this code is free to use, modify, copy, or distribute provided it is for academic use and source code developers are properly acknowledged and cited. The CAESAR-Lisflood model is freely available for academic use; a Windows-based compiled version of the model and the source code (C sharp) can be downloaded from https://sourceforge.net/projects/ caesar-lisflood/ (Coulthard, 2020).

Supplement. The supplement related to this article is available online at: https://doi.org/10.5194/esurf-8-17-2020-supplement.

Author contributions. NP carried out the numerical experiment, produced the figures, and wrote the article. CS assisted in setting the CAESAR-Lisflood model and provided guidance in the geomorphic analysis. NP, SF, and PM designed the project. All authors contributed to the article edits.

Competing interests. The authors declare that they have no conflict of interest.

Acknowledgements. We thank MeteoSwiss, the Swiss Federal Office of Meteorology and Climatology, for supplying climate data from ground stations and gridded products, the Swiss Federal Office for the Environment for supplying the streamflow data, the Swiss Federal Statistical Office for supplying the land use map, and the Swiss Federal Office of Topography for supplying the digital elevation model and the bedrock map. Nadav Peleg thanks Giulia Battista for many fruitful discussions during the preparation of this paper.

Financial support. Nadav Peleg is funded by the Swiss Competence Center for Energy Research - Supply of Electricity. Chris Skinner was funded by the NERC Flash Flooding from Intense Rainfall (FFIR) project, Susceptibility of Basins to Intense Rainfall and Flooding (SINATRA) NE/K008668/1.

Review statement. This paper was edited by Jean Braun and reviewed by two anonymous referees.

\section{References}

Alexander, L. V., Zhang, X., Peterson, T. C., Caesar, J., Gleason, B., Tank, A., Haylock, M., Collins, D., Trewin, B., Rahimzadeh, F., Tagipour, A., Kumar, K. R., Revadekar, J., Griffiths, G., Vincent, L., Stephenson, D. B., Burn, J., Aguilar, E., Brunet, M., Taylor, M., New, M., Zhai, P., Rusticucci, M., and Vazquez-Aguirre, J. L.: Global observed changes in daily climate extremes of temperature and precipitation, J. Geophys. Res.-Atmos., 111, D05109, https://doi.org/10.1029/2005jd006290, 2006. 
Amponsah, W., Marchi, L., Zoccatelli, D., Boni, G., Cavalli, M., Comiti, F., Crema, S., Lucia, A., Marra, F., and Borga, M.: Hydrometeorological Characterization of a Flash Flood Associated with Major Geomorphic Effects: Assessment of Peak Discharge Uncertainties and Analysis of the Runoff Response, J. Hydrometeorol., 17, 3063-3077, https://doi.org/10.1175/jhm-d16-0081.1, 2016.

Arnaud, P., Lavabre, J., Fouchier, C., Diss, S., and Javelle, P.: Sensitivity of hydrological models to uncertainty in rainfall input, Hydrolog. Sci. J., 56, 397-410, https://doi.org/10.1080/02626667.2011.563742, 2011.

Bahat, Y., Grodek, T., Lekach, J., and Morin, E.: Rainfall-runoff modeling in a small hyper-arid catchment, J. Hydrol., 373, 204 217, https://doi.org/10.1016/j.jhydrol.2009.04.026, 2009.

Ban, N., Schmidli, J., and Schar, C.: Evaluation of the convectionresolving regional climate modeling approach in decadelong simulations, J. Geophys. Res.-Atmos., 119, 7889-7907, https://doi.org/10.1002/2014jd021478, 2014

Ban, N., Schmidli, J., and Schar, C.: Heavy precipitation in a changing climate: Does short-term summer precipitation increase faster?, Geophys. Res. Lett., 42, 1165-1172, https://doi.org/10.1002/2014gl062588, 2015.

Bates, P. D., Horritt, M. S., and Fewtrell, T. J.: A simple inertial formulation of the shallow water equations for efficient twodimensional flood inundation modelling, J. Hydrol., 387, 33-45, https://doi.org/10.1016/j.jhydrol.2010.03.027, 2010.

Battista, G., Molnar, P., and Burlando, P.: Modelling impacts of spatially variable erosion drivers on suspended sediment dynamics, Earth Surf. Dynam. Discuss., https://doi.org/10.5194/esurf2019-59, in review, 2019.

Belachsen, I., Marra, F., Peleg, N., and Morin, E.: Convective rainfall in a dry climate: relations with synoptic systems and flashflood generation in the Dead Sea region, Hydrol. Earth Syst. Sci., 21, 5165-5180, https://doi.org/10.5194/hess-21-5165-2017, 2017.

Bell, T. L.: A space-time stochastic model of rainfall for satellite remote-sensing studies, J. Geophys. Res.-Atmos., 92, 9631-9643, https://doi.org/10.1029/JD092iD08p09631, 1987.

Bell, V. A. and Moore, R. J.: The sensitivity of catchment runoff models to rainfall data at different spatial scales, Hydrol. Earth Syst. Sci., 4, 653-667, https://doi.org/10.5194/hess-4-653-2000, 2000.

Beniston, M.: August 2005 intense rainfall event in Switzerland: Not necessarily an analog for strong convective events in a greenhouse climate, Geophys. Res. Lett., 33, L05701, https://doi.org/10.1029/2005g1025573, 2006.

Benoit, L., Allard, D., and Mariethoz, G.: Stochastic Rainfall Modeling at Sub-kilometer Scale, Water Resour. Res., 54, 41084130, https://doi.org/10.1029/2018wr022817, 2018a.

Benoit, L., Vrac, M., and Mariethoz, G.: Dealing with nonstationarity in sub-daily stochastic rainfall models, Hydrol. Earth Syst. Sci., 22, 5919-5933, https://doi.org/10.5194/hess-22-59192018, 2018b.

Berg, P., Moseley, C., and Haerter, J. O.: Strong increase in convective precipitation in response to higher temperatures, Nat. Geosci., 6, 181-185, https://doi.org/10.1038/ngeo1731, 2013.

Beven, K. J. and Kirkby, M. J.: A physically based, variable contributing area model of basin hydrology/Un modèle à base physique de zone d'appel variable de l'hydrologie du bassin versant, Hydrol. Sci. B., 24, 43-69, https://doi.org/10.1080/02626667909491834, 1979.

Bezzola, G. R. and Hegg, C.: Ereignisanalyse Hochwasser 2005, Teil 2-Analyse von Prozessen, Massnahmen und Gefahrengrundlagen, Bundesamt für Umwelt BAFU, Eidgenössische Forschungsanstalt WSL, Umwelt-Wissen, 8, 429, 2008.

Blöschl, G., Hall, J., Parajka, J., Perdigao, R. A. P., Merz, B., Arheimer, B., Aronica, G. T., Bilibashi, A., Bonacci, O., Borga, M., Canjevac, I., Castellarin, A., Chirico, G. B., Claps, P., Fiala, K., Frolova, N., Gorbachova, L., Gul, A., Hannaford, J., Harrigan, S., Kireeva, M., Kiss, A., Kjeldsen, T. R., Kohnova, S., Koskela, J. J., Ledvinka, O., Macdonald, N., MavrovaGuirguinova, M., Mediero, L., Merz, R., Molnar, P., Montanari, A., Murphy, C., Osuch, M., Ovcharuk, V., Radevski, I., Rogger, M., Salinas, J. L., Sauquet, E., Sraj, M., Szolgay, J., Viglione, A., Volpi, E., Wilson, D., Zaimi, K., and Zivkovic, N.: Changing climate shifts timing of European floods, Science, 357, 588-590, https://doi.org/10.1126/science.aan2506, 2017.

Blum, M. D. and Tornqvist, T. E.: Fluvial responses to climate and sea-level change: a review and look forward, Sedimentology, 47, 2-48, https://doi.org/10.1046/j.1365-3091.2000.00008.x, 2000.

Borga, M., Stoffel, M., Marchi, L., Marra, F., and Jakob, M.: Hydrogeomorphic response to extreme rainfall in headwater systems: Flash floods and debris flows, J. Hydrol., 518, 194-205, https://doi.org/10.1016/j.jhydrol.2014.05.022, 2014

Coulthard, T. J.: CAESAR-Lisflood code, version “j”, available at: https://sourceforge.net/projects/caesar-lisflood/, last access: 6 January 2020.

Coulthard, T. J. and Skinner, C. J.: The sensitivity of landscape evolution models to spatial and temporal rainfall resolution, Earth Surf. Dynam., 4, 757-771, https://doi.org/10.5194/esurf-4-7572016, 2016.

Coulthard, T. J. and Van De Wiel, M. J.: Modelling long term basin scale sediment connectivity, driven by spatial land use changes, Geomorphology, 277, 265-281, https://doi.org/10.1016/j.geomorph.2016.05.027, 2017.

Coulthard, T. J., Macklin, M. G., and Kirkby, M. J.: A cellular model of Holocene upland river basin and alluvial fan evolution, Earth Surf. Proc. Land., 27, 269-288, https://doi.org/10.1002/esp.318, 2002.

Coulthard, T. J., Hancock, G. R., and Lowry, J. B. C.: Modelling soil erosion with a downscaled landscape evolution model, Earth Surf. Proc. Land., 37, 1046-1055, https://doi.org/10.1002/esp.3226, 2012a.

Coulthard, T. J., Ramirez, J., Fowler, H. J., and Glenis, V.: Using the UKCP09 probabilistic scenarios to model the amplified impact of climate change on drainage basin sediment yield, Hydrol. Earth Syst. Sci., 16, 4401-4416, https://doi.org/10.5194/hess-16-44012012, 2012b.

Coulthard, T. J., Neal, J. C., Bates, P. D., Ramirez, J., de Almeida, G. A. M., and Hancock, G. R.: Integrating the LISFLOOD-FP 2D hydrodynamic model with the CAESAR model: implications for modelling landscape evolution, Earth Surf. Proc. Land., 38, 1897-1906, https://doi.org/10.1002/esp.3478, 2013.

Dahm, R., Bhardwaj, A., Weiland, F. S., Corzo, G., and Bouwer, L. M.: A Temperature-Scaling Approach for Projecting Changes in Short Duration Rainfall Extremes from GCM Data, Water, 11, 313, https://doi.org/10.3390/w11020313, 2019. 
Dams, J., Nossent, J., Senbeta, T. B., Willems, P., and Batelaan, O.: Multi-model approach to assess the impact of climate change on runoff, J. Hydrol., 529, 1601-1616, https://doi.org/10.1016/j.jhydrol.2015.08.023, 2015.

Deal, E., Favre, A. C., and Braun, J.: Rainfall variability in the Himalayan orogen and its relevance to erosion processes, Water Resour. Res., 53, 4004-4021, https://doi.org/10.1002/2016wr020030, 2017.

Death, R. G., Fuller, I. C., and Macklin, M. G.: Resetting the river template: the potential for climate-related extreme floods to transform river geomorphology and ecology, Freshwater Biol., 60, 2477-2496, https://doi.org/10.1111/fwb.12639, 2015.

Destro, E., Amponsah, W., Nikolopoulos, E. I., Marchi, L., Marra, F., Zoccatelli, D., and Borga, M.: Coupled prediction of flash flood response and debris flow occurrence: Application on an alpine extreme flood event, J. Hydrol., 558, 225-237, https://doi.org/10.1016/j.jhydrol.2018.01.021, 2018.

Do, H. X., Westra, S., and Leonard, M.: A global-scale investigation of trends in annual maximum streamflow, J. Hydrol., 552, 28-43, https://doi.org/10.1016/j.jhydrol.2017.06.015, 2017.

Einstein, H. A.: The bed-load function for sediment transportation in open channel flows, USDA Soil Conservation Service, 1950.

Fadhel, S., Rico-Ramirez, M. A., and Han, D. W.: Sensitivity of peak flow to the change of rainfall temporal pattern due to warmer climate, J. Hydrol., 560, 546-559, https://doi.org/10.1016/j.jhydrol.2018.03.041, 2018.

Fatichi, S., Rimkus, S., Burlando, P., and Bordoy, R.: Does internal climate variability overwhelm climate change signals in streamflow? The upper Po and Rhone basin case studies, Sci. Total Environ., 493, 1171-1182, https://doi.org/10.1016/j.scitotenv.2013.12.014, 2014.

Fatichi, S., Rimkus, S., Burlando, P., Bordoy, R., and Molnar, P.: High-resolution distributed analysis of climate and anthropogenic changes on the hydrology of an Alpine catchment, J. Hydrol., 525, 362-382, https://doi.org/10.1016/j.jhydrol.2015.03.036, 2015.

Fatichi, S., Vivoni, E. R., Ogden, F. L., Ivanov, V. Y., Mirus, B., Gochis, D., Downer, C. W., Camporese, M., Davison, J. H., Ebel, B., Jones, N., Kim, J., Mascaro, G., Niswonger, R., Restrepo, P., Rigon, R., Shen, C., Sulis, M., and Tarboton, D.: An overview of current applications, challenges, and future trends in distributed process-based models in hydrology, J. Hydrol., 537, 45-60, https://doi.org/10.1016/j.jhydrol.2016.03.026, 2016.

Fischer, E. M. and Knutti, R.: Anthropogenic contribution to global occurrence of heavy-precipitation and hightemperature extremes, Nat. Clim. Change, 5, 560-564, https://doi.org/10.1038/nclimate2617, 2015.

Fischer, E. M. and Knutti, R.: Observed heavy precipitation increase confirms theory and early models, Nat. Clim. Change, 6, 986991, https://doi.org/10.1038/nclimate3110, 2016.

Fischer, E. M., Beyerle, U., and Knutti, R.: Robust spatially aggregated projections of climate extremes, Nat. Clim. Change, 3, 1033-1038, https://doi.org/10.1038/nclimate2051, 2013.

Francipane A., Fatichi, S., Ivanov, V. Y., and Noto, L. V.: Stochastic assessment of climate impacts on hydrology and geomorphology of semiarid headwater basins using a physically-based model, J. Geophys. Res.-Earth, 120, 507-533, https://doi.org/10.1002/2014JF003232, 2015.
Gaál, L., Molnar, P., and Szolgay, J.: Selection of intense rainfall events based on intensity thresholds and lightning data in Switzerland, Hydrol. Earth Syst. Sci., 18, 1561-1573, https://doi.org/10.5194/hess-18-1561-2014, 2014.

Gires, A., Giangola-Murzyn, A., Abbes, J. B., Tchiguirinskaia, I., Schertzer, D., and Lovejoy, S.: Impacts of small scale rainfall variability in urban areas: a case study with $1 \mathrm{D}$ and $1 \mathrm{D} / 2 \mathrm{D}$ hydrological models in a multifractal framework, Urban Water J., 12, 607-617, https://doi.org/10.1080/1573062x.2014.923917, 2015.

Goodrich, D. C., Faures, J. M., Woolhiser, D. A., Lane, L. J., and Sorooshian, S.: measurement and analysis of small-scale convective storm rainfall variability, J. Hydrol., 173, 283-308, https://doi.org/10.1016/0022-1694(95)02703-r, 1995.

Goudie, A. S.: Global warming and fluvial geomorphology, Geomorphology, 79, 384-394, https://doi.org/10.1016/j.geomorph.2006.06.023, 2006.

Gupta, V. K., Castro, S. L., and Over, T. M.: On scaling exponents of spatial peak flows from rainfall and river network geometry, J. Hydrol., 187, 81-104, https://doi.org/10.1016/s00221694(96)03088-0, 1996.

Guzzetti, F., Peruccacci, S., Rossi, M., and Stark, C. P.: The rainfall intensity-duration control of shallow landslides and debris flows: an update, Landslides, 5, 3-17, https://doi.org/10.1007/s10346007-0112-1, 2008.

Haerter, J. O.: Convective Self-Aggregation As a Cold PoolDriven Critical Phenomenon, Geophys. Res. Lett., 46, 40174028, https://doi.org/10.1029/2018gl081817, 2019.

Haerter, J. O., Berg, P., and Moseley, C.: Precipitation onset as the temporal reference in convective selforganization, Geophys. Res. Lett., 44, 6450-6459, https://doi.org/10.1002/2017gl073342, 2017.

Hancock, G. R.: A catchment scale assessment of increased rainfall and storm intensity on erosion and sediment transport for Northern Australia, Geoderma, 152, 350-360, https://doi.org/10.1016/j.geoderma.2009.07.003, 2009.

Hancock, G. R.: Modelling stream sediment concentration: An assessment of enhanced rainfall and storm frequency, J. Hydrol., 430, 1-12, https://doi.org/10.1016/j.jhydrol.2012.01.022, 2012.

Hancock, G. R. and Coulthard, T. J.: Channel movement and erosion response to rainfall variability in southeast Australia, Hydrol. Process., 26, 663-673, https://doi.org/10.1002/hyp.8166, 2012.

Hancock, G. R., Lowry, J. B. C., Coulthard, T. J., Evans, K. G., and Moliere, D. R.: A catchment scale evaluation of the SIBERIA and CAESAR landscape evolution models, Earth Surf. Proc. Land., 35, 863-875, https://doi.org/10.1002/esp.1863, 2010.

Hancock, G. R., Lowry, J. B. C., and Coulthard, T. J.: Catchment reconstruction - erosional stability at millennial time scales using landscape evolution models, Geomorphology, 231, 15-27, https://doi.org/10.1016/j.geomorph.2014.10.034, 2015.

Heimann, F. U. M., Rickenmann, D., Böckli, M., Badoux, A., Turowski, J. M., and Kirchner, J. W.: Calculation of bedload transport in Swiss mountain rivers using the model sedFlow: proof of concept, Earth Surf. Dynam., 3, 35-54, https://doi.org/10.5194/esurf-3-35-2015, 2015.

Hoober, D., Svoray, T., and Cohen, S.: Using a landform evolution model to study ephemeral gullying in agricultural fields: the effects of rainfall patterns on ephemeral 
gully dynamics, Earth Surf. Proc. Land., 42, 1213-1226, https://doi.org/10.1002/esp.4090, 2017.

Isotta, F. A., Frei, C., Weilguni, V., Tadic, M. P., Lassegues, P., Rudolf, B., Pavan, V., Cacciamani, C., Antolini, G., Ratto, S. M., Munari, M., Micheletti, S., Bonati, V., Lussana, C., Ronchi, C., Panettieri, E., Marigo, G., and Vertacnik, G.: The climate of daily precipitation in the Alps: development and analysis of a highresolution grid dataset from pan-Alpine rain-gauge data, Int. J. Climatol., 34, 1657-1675, https://doi.org/10.1002/joc.3794, 2014.

Istanbulluoglu, E. and Bras, R. L.: On the dynamics of soil moisture, vegetation, and erosion: Implications of climate variability and change, Water Resour. Res., 42, W06418, https://doi.org/10.1029/2005wr004113, 2006.

Iverson, R. M.: Landslide triggering by rain infiltration, Water Resour. Res., 36, 1897-1910, https://doi.org/10.1029/2000wr900090, 2000.

Jacob, D., Petersen, J., Eggert, B., Alias, A., Christensen, O. B., Bouwer, L. M., Braun, A., Colette, A., Deque, M., Georgievski, G., Georgopoulou, E., Gobiet, A., Menut, L., Nikulin, G., Haensler, A., Hempelmann, N., Jones, C., Keuler, K., Kovats, S., Kroner, N., Kotlarski, S., Kriegsmann, A., Martin, E., van Meijgaard, E., Moseley, C., Pfeifer, S., Preuschmann, S., Radermacher, C., Radtke, K., Rechid, D., Rounsevell, M., Samuelsson, P., Somot, S., Soussana, J. F., Teichmann, C., Valentini, R., Vautard, R., Weber, B., and Yiou, P.: EUROCORDEX: new high-resolution climate change projections for European impact research, Reg. Environ. Change, 14, 563-578, https://doi.org/10.1007/s10113-013-0499-2, 2014.

Jaeggi, M.: The floods of August 22-23, 2005, in Switzerland: some facts and challenges, in: Gravel-Bed Rivers Vi: From Process Understanding to River Restoration, edited by: Habersack, H., Piegay, H., and Rinaldi, M., Developments in Earth Surface Processes, 587-604, 2008

Kalinga, O. A. and Gan, T. Y.: Semi-distributed modelling of basin hydrology with radar and gauged precipitation, Hydrol. Process., 20, 3725-3746, https://doi.org/10.1002/hyp.6385, 2006.

Kampf, S. K., Brogan, D. J., Schmeer, S., MacDonald, L. H., and Nelson, P. A.: How do geomorphic effects of rainfall vary with storm type and spatial scale in a post-fire landscape?, Geomorphology, 273, 39-51, https://doi.org/10.1016/j.geomorph.2016.08.001, 2016.

Krapesch, G., Hauer, C., and Habersack, H.: Scale orientated analysis of river width changes due to extreme flood hazards, Nat. Hazards Earth Syst. Sci., 11, 2137-2147, https://doi.org/10.5194/nhess-11-2137-2011, 2011.

Kundu, P. K. and Bell, T. L.: A stochastic model of space-time variability of mesoscale rainfall: Statistics of spatial averages, Water Resour. Res., 39, 1328, https://doi.org/10.1029/2002wr001802, 2003.

Lane, S. N., Bakker, M., Gabbud, C., Micheletti, N., and Saugy, J. N.: Sediment export, transient landscape response and catchment-scale connectivity following rapid climate warming and Alpine glacier recession, Geomorphology, 277, 210-227, https://doi.org/10.1016/j.geomorph.2016.02.015, 2017.

Lenderink, G. and Attema, J.: A simple scaling approach to produce climate scenarios of local precipitation extremes for the Netherlands, Environ. Res. Lett., 10, 085001, https://doi.org/10.1088/1748-9326/10/8/085001, 2015.
Lenderink, G. and Van Meijgaard, E.: Increase in hourly precipitation extremes beyond expectations from temperature changes, Nat. Geosci., 1, 511-514, https://doi.org/10.1038/ngeo262, 2008.

Leonarduzzi, E., Molnar, P., and McArdell, B. W.: Predictive performance of rainfall thresholds for shallow landslides in Switzerland from gridded daily data, Water Resour. Res., 53, 6612-6625, https://doi.org/10.1002/2017wr021044, 2017.

Li, J., Wasko, C., Johnson, F., Evans, J. P., and Sharma, A.: Can Regional Climate Modeling Capture the Observed Changes in Spatial Organization of Extreme Storms at Higher Temperatures?, Geophys. Res. Lett., 45, 4475-4484, https://doi.org/10.1029/2018gl077716, 2018.

Li, Z. Y. and Fang, H. Y.: Impacts of climate change on water erosion: A review, Earth-Sci. Rev., 163, 94-117, https://doi.org/10.1016/j.earscirev.2016.10.004, 2016.

Lochbihler, K., Lenderink, G., and Siebesma, A. P.: The spatial extent of rainfall events and its relation to precipitation scaling, Geophys. Res. Lett., 44, 8629-8636, https://doi.org/10.1002/2017gl074857, 2017.

Lopes, V. L.: On the effect of uncertainty in spatial distribution of rainfall on catchment modelling, Catena, 28, 107-119, https://doi.org/10.1016/s0341-8162(96)00030-6, 1996.

Mallakpour, I. and Villarini, G.: The changing nature of flooding across the central United States, Nat. Clim. Change, 5, 250-254, https://doi.org/10.1038/nclimate2516, 2015.

Marchi, L., Borga, M., Preciso, E., and Gaume, E.: Characterisation of selected extreme flash floods in Europe and implications for flood risk management, J. Hydrol., 394, 118-133, https://doi.org/10.1016/j.jhydrol.2010.07.017, 2010.

Marra, F. and Morin, E.: Autocorrelation structure of convective rainfall in semiarid-arid climate derived from highresolution X-Band radar estimates, Atmos. Res., 200, 126-138, https://doi.org/10.1016/j.atmosres.2017.09.020, 2018.

Mastrotheodoros, T., Pappas, C., Molnar, P., Burlando, P., Hadjidoukas, P., and Fatichi, S.: Ecohydrological dynamics in the Alps: Insights from a modelling analysis of the spatial variability, Ecohydrology, 12, e2054, https://doi.org/10.1002/eco.2054, 2019.

McRobie, F. H., Wang, L. P., Onof, C., and Kenney, S.: A spatialtemporal rainfall generator for urban drainage design, Water Sci. Technol., 68, 240-249, https://doi.org/10.2166/wst.2013.241, 2013.

MeteoSwiss: Documentation of MeteoSwiss Grid-Data Products: Daily Precipitation (final analysis): RhiresD, Tech rep., Federal Office of Meteorology and Climatology MeteoSwiss, Federal Department of Home Affairs FDHA, Switzerland, available at: https://www.meteoswiss.admin.ch/ content/dam/meteoswiss/de/service-und-publikationen/produkt/ raeumliche-daten-niederschlag/doc/ProdDoc_RhiresD.pdf (last access: 6 January 2020), 2016.

Mishra, V., Wallace, J. M., and Lettenmaier, D. P.: Relationship between hourly extreme precipitation and local air temperature in the United States, Geophys. Res. Lett., 39, L16403, https://doi.org/10.1029/2012gl052790, 2012.

Molnar, P., Fatichi, S., Gaál, L., Szolgay, J., and Burlando, P.: Storm type effects on super Clausius-Clapeyron scaling of intense rainstorm properties with air temperature, Hydrol. Earth 
Syst. Sci., 19, 1753-1766, https://doi.org/10.5194/hess-19-17532015, 2015.

Morin, E., Goodrich, D. C., Maddox, R. A., Gao, X. G., Gupta, H. V., and Sorooshian, S.: Spatial patterns in thunderstorm rainfall events and their coupling with watershed hydrological response, Adv. Water Resour., 29, 843-860, https://doi.org/10.1016/j.advwatres.2005.07.014, 2006.

Nash, J. E. and Sutcliffe, J. V.: River flow forecasting through conceptual models part I - A discussion of principles, J. Hydrol., 10, 282-290, https://doi.org/10.1016/0022-1694(70)90255-6, 1970.

Nearing, M. A., Pruski, F. F., and O’Neal, M. R.: Expected climate change impacts on soil erosion rates: A review, J. Soil Water Conserv., 59, 43-50, 2004.

Nearing, M. A., Jetten, V., Baffaut, C., Cerdan, O., Couturier, A., Hernandez, M., Le Bissonnais, Y., Nichols, M. H., Nunes, J. P., Renschler, C. S., Souchere, V., and van Oost, K.: Modeling response of soil erosion and runoff to changes in precipitation and cover, Catena, 61, 131-154, https://doi.org/10.1016/j.catena.2005.03.007, 2005.

O, S. and Foelsche, U.: Assessment of spatial uncertainty of heavy rainfall at catchment scale using a dense gauge network, Hydrol. Earth Syst. Sci., 23, 2863-2875, https://doi.org/10.5194/hess-232863-2019, 2019.

Ochoa-Rodriguez, S., Wang, L. P., Gires, A., Pina, R. D., ReinosoRondinel, R., Bruni, G., Ichiba, A., Gaitan, S., Cristiano, E., van Assel, J., Kroll, S., Murla-Tuyls, D., Tisserand, B., Schertzer, D., Tchiguirinskaia, I., Onof, C., Willems, P., and ten Veldhuis, M. C.: Impact of spatial and temporal resolution of rainfall inputs on urban hydrodynamic modelling outputs: A multi-catchment investigation, J. Hydrol., 531, 389-407, https://doi.org/10.1016/j.jhydrol.2015.05.035, 2015.

O'Gorman, P. A. and Schneider, T.: Scaling of Precipitation Extremes over a Wide Range of Climates Simulated with an Idealized GCM, J. Climate, 22, 5676-5685, https://doi.org/10.1175/2009jcli2701.1, 2009.

Orlowsky, B. and Seneviratne, S. I.: Global changes in extreme events: regional and seasonal dimension, Climatic Change, 110, 669-696, https://doi.org/10.1007/s10584-011-0122-9, 2012.

Pandey, A., Himanshu, S. K., Mishra, S. K., and Singh, V. P.: Physically based soil erosion and sediment yield models revisited, Catena, 147, 595-620, https://doi.org/10.1016/j.catena.2016.08.002, 2016.

Paniconi, C. and Putti, M.: Physically based modeling in catchment hydrology at 50: Survey and outlook, Water Resour. Res., 51, 7090-7129, https://doi.org/10.1002/2015WR017780, 2015.

Panziera, L., James, C. N., and Germann, U.: Mesoscale organization and structure of orographic precipitation producing flash floods in the Lago Maggiore region, Q. J. Roy. Meteor. Soc., 141, 224-248, https://doi.org/10.1002/qj.2351, 2015.

Panziera, L., Gabella, M., Germann, U., and Martins, O.: A 12-year radar-based climatology of daily and sub-daily extreme precipitation over the Swiss Alps, Int. J. Climatol., 38, 3749-3769, https://doi.org/10.1002/joc.5528, 2018.

Paschalis, A., Molnar, P., Fatichi, S., and Burlando, P.: A stochastic model for high-resolution space-time precipitation simulation, Water Resour. Res., 49, 8400-8417, https://doi.org/10.1002/2013wr014437, 2013.

Paschalis, A., Fatichi, S., Molnar, P., Rimkus, S., and Burlando, P.: On the effects of small scale space-time variability of rainfall on basin flood response, J. Hydrol., 514, 313-327, https://doi.org/10.1016/j.jhydrol.2014.04.014, 2014.

Pegram, G. G. S. and Clothier, A. N.: High resolution space-time modelling of rainfall: the "String of Beads" model, J. Hydrol., 241, 26-41, https://doi.org/10.1016/s00221694(00)00373-5, 2001a.

Pegram, G. G. S. and Clothier, A. N.: Downscaling rainfields in space and time, using the String of Beads model in time series mode, Hydrol. Earth Syst. Sci., 5, 175-186, https://doi.org/10.5194/hess-5-175-2001, 2001b.

Peleg, N. and Morin, E.: Convective rain cells: Radar-derived spatiotemporal characteristics and synoptic patterns over the eastern Mediterranean, J. Geophys. Res.-Atmos., 117, D15116, https://doi.org/10.1029/2011jd017353, 2012.

Peleg, N. and Morin, E.: Stochastic convective rain-field simulation using a high-resolution synoptically conditioned weather generator (HiReS-WG), Water Resour. Res., 50, 2124-2139, https://doi.org/10.1002/2013wr014836, 2014.

Peleg, N., Ben-Asher, M., and Morin, E.: Radar subpixel-scale rainfall variability and uncertainty: lessons learned from observations of a dense rain-gauge network, Hydrol. Earth Syst. Sci., 17, 2195-2208, https://doi.org/10.5194/hess-17-2195-2013, 2013.

Peleg, N., Shamir, E., Georgakakos, K. P., and Morin, E.: A framework for assessing hydrological regime sensitivity to climate change in a convective rainfall environment: a case study of two medium-sized eastern Mediterranean catchments, Israel, Hydrol. Earth Syst. Sci., 19, 567-581, https://doi.org/10.5194/hess-19567-2015, 2015.

Peleg, N., Blumensaat, F., Molnar, P., Fatichi, S., and Burlando, P.: Partitioning the impacts of spatial and climatological rainfall variability in urban drainage modeling, Hydrol. Earth Syst. Sci., 21, 1559-1572, https://doi.org/10.5194/hess-21-1559-2017, 2017a.

Peleg, N., Fatichi, S., Paschalis, A., Molnar, P., and Burlando, P.: An advanced stochastic weather generator for simulating 2-D highresolution climate variables, J. Adv. Model. Earth Sy., 9, 15951627, https://doi.org/10.1002/2016ms000854, 2017 b.

Peleg, N., Marra, F., Fatichi, S., Molnar, P., Morin, E., Sharma, A., and Burlando, P.: Intensification of Convective Rain Cells at Warmer Temperatures Observed from HighResolution Weather Radar Data, J. Hydrometeorol., 19, 715-726, https://doi.org/10.1175/jhm-d-17-0158.1, 2018a.

Peleg, N., Marra, F., Fatichi, S., Paschalis, A., Molnar, P., and Burlando, P.: Spatial variability of extreme rainfall at radar subpixel scale, J. Hydrol., 556, 922-933, https://doi.org/10.1016/j.jhydrol.2016.05.033, 2018b.

Peleg, N., Molnar, P., Burlando, P., and Fatichi, S.: Exploring stochastic climate uncertainty in space and time using a gridded hourly weather generator, J. Hydrol., 571, 627-641, https://doi.org/10.1016/j.jhydrol.2019.02.010, 2019.

Perra, E., Piras, M., Deidda, R., Paniconi, C., Mascaro, G., Vivoni, E. R., Cau, P., Marras, P. A., Ludwig, R., and Meyer, S.: Multimodel assessment of climate change-induced hydrologic impacts for a Mediterranean catchment, Hydrol. Earth Syst. Sci., 22, 4125-4143, https://doi.org/10.5194/hess-22-4125-2018, 2018.

Peterson, T. C., Heim, R. R., Hirsch, R., Kaiser, D. P., Brooks, H., Diffenbaugh, N. S., Dole, R. M., Giovannettone, J. P., Guirguis, K., Karl, T. R., Katz, R. W., Kunkel, K., Lettenmaier, D., McCabe, G. J., Paciorek, C. J., Ryberg, K. R., Schubert, S., Silva, 
V. B. S., Stewart, B. C., Vecchia, A. V., Villarini, G., Vose, R. S., Walsh, J., Wehner, M., Wolock, D., Wolter, K., Woodhouse, C. A., and Wuebbles, D.: Monitoring and understanding changes in heat waves, cold waves, floods, and droughts in the United States: state of knowledge, B. Am. Meteorol. Soc., 94, 821-834, https://doi.org/10.1175/bams-d-12-00066.1, 2013.

Pfahl, S., O'Gorman, P. A., and Fischer, E. M.: Understanding the regional pattern of projected future changes in extreme precipitation, Nat. Clim. Change, 7, 423-427, https://doi.org/10.1038/nclimate3287, 2017.

Prein, A. F., Langhans, W., Fosser, G., Ferrone, A., Ban, N., Goergen, K., Keller, M., Tolle, M., Gutjahr, O., Feser, F., Brisson, E., Kollet, S., Schmidli, J., van Lipzig, N. P. M., and Leung, R.: A review on regional convection-permitting climate modeling: Demonstrations, prospects, and challenges, Rev. Geophys., 53, 323-361, https://doi.org/10.1002/2014rg000475, 2015.

Prein, A. F., Liu, C. H., Ikeda, K., Trier, S. B., Rasmussen, R. M., Holland, G. J., and Clark, M. P.: Increased rainfall volume from future convective storms in the US, Nat. Clim. Change, 7, 880884, https://doi.org/10.1038/s41558-017-0007-7, 2017.

Ramsankaran, R., Kothyari, U. C., Ghosh, S. K., Malcherek, A., and Murugesan, K.: Physically-based distributed soil erosion and sediment yield model (DREAM) for simulating individual storm events, Hydrolog. Sci. J., 58, 872-891, https://doi.org/10.1080/02626667.2013.781606, 2013.

Rickenmann, D. and Koschni, A.: Sediment loads due to fluvial transport and debris flows during the 2005 flood events in Switzerland, Hydrol. Process., 24, 993-1007, https://doi.org/10.1002/hyp.7536, 2010 .

Rickenmann, D. and McArdell, B. W.: Continuous measurement of sediment transport in the Erlenbach stream using piezoelectric bedload impact sensors, Earth Surf. Proc. Land., 32, 1362-1378, https://doi.org/10.1002/esp.1478, 2007.

Rickenmann, D., Hunzinger, L., and Koschni, A.: Hochwasser und Sedimenttransport während des Unwetters vom August 2005 in der Schweiz, 11th congress INTERPRAEVENT, 2008, Conference Proceedings, Vol. 1, 465-476, 2008.

Rickenmann, D., Badoux, A., and Hunzinger, L.: Significance of sediment transport processes during piedmont floods: the 2005 flood events in Switzerland, Earth Surf. Proc. Land., 41, 224230, https://doi.org/10.1002/esp.3835, 2016.

Schwarb, M.: The alpine precipitation climate: Evaluation of a highresolution analysis scheme using comprehensive rain-gauge data, $\mathrm{PhD}$ thesis, Swiss Fed. Inst. of Technol., Zurich, Switzerland, 131 pp., 2000.

Shah, S. M. S., Oconnell, P. E., and Hosking, J. R. M.: Modelling the effects of spatial variability in rainfall on catchment response .1. Formulation and calibration of a stochastic rainfall field model, J. Hydrol., 175, 67-88, https://doi.org/10.1016/s00221694(96)80006-0, 1996a.

Shah, S. M. S., Oconnell, P. E., and Hosking, J. R. M.: Modelling the effects of spatial variability in rainfall on catchment response .2. Experiments with distributed and lumped models, J. Hydrol., 175, 89-111, https://doi.org/10.1016/s00221694(96)80007-2, 1996b.

Sharma, A., Wasko, C., and Lettenmaier, D. P.: If Precipitation Extremes Are Increasing, Why Aren't Floods?, Water Resour. Res., 54, 8545-8551, https://doi.org/10.1029/2018wr023749, 2018.
Shen, H. O., Zheng, F. L., Wen, L. L., Han, Y., and Hu, W. Impacts of rainfall intensity and slope gradient on rill erosion processes at loessial hillslope, Soil Till. Res., 155, 429-436, https://doi.org/10.1016/j.still.2015.09.011, 2016.

Singer, M. B., Michaelides, K., and Hobley, D. E. J.: STORM 1.0: a simple, flexible, and parsimonious stochastic rainfall generator for simulating climate and climate change, Geosci. Model Dev., 11, 3713-3726, https://doi.org/10.5194/gmd-113713-2018, 2018.

Singh, D., Tsiang, M., Rajaratnam, B., and Diffenbaugh, N. S.: Observed changes in extreme wet and dry spells during the South Asian summer monsoon season, Nat. Clim. Change, 4, 456-461, https://doi.org/10.1038/nclimate2208, 2014.

Singh, V. P.: Effect of spatial and temporal variability in rainfall and watershed characteristics on stream flow hydrograph, Hydrol. Process., 11, 1649-1669, https://doi.org/10.1002/(sici)10991085(19971015)11:12<1649::Aid-hyp495>3.0.Co;2-1, 1997.

Skinner, C. J., Coulthard, T. J., Schwanghart, W., Van De Wiel, M. J., and Hancock, G.: Global sensitivity analysis of parameter uncertainty in landscape evolution models, Geosci. Model Dev., 11, 4873-4888, https://doi.org/10.5194/gmd-11-4873-2018, 2018.

Skinner, C. J., Peleg, N., Quinn, N., Coulthard, T., J., Molnar, P., and Freer, J.: Demonstrating the impact of rainfall product uncertainty on geomorphic modelling, Earth Surf. Proc. Land., in review, 2020.

Steeb, N., Rickenmann, D., Badoux, A., Rickli, C., and Waldner, P.: Large wood recruitment processes and transported volumes in Swiss mountain streams during the extreme flood of August 2005, Geomorphology, 279, 112-127, https://doi.org/10.1016/j.geomorph.2016.10.011, 2017.

Te Chow, V.: Open-channel hydraulics, McGraw-Hill New York, 1959.

Thompson, C. and Croke, J.: Geomorphic effects, flood power, and channel competence of a catastrophic flood in confined and unconfined reaches of the upper Lockyer valley, southeast Queensland, Australia, Geomorphology, 197, 156-169, https://doi.org/10.1016/j.geomorph.2013.05.006, 2013.

Trenberth, K. E., Dai, A., Rasmussen, R. M., and Parsons, D. B.: The changing character of precipitation, B. Am. Meteorol. Soc., 84, 1205-1217, https://doi.org/10.1175/bams-84-9-1205, 2003.

Tucker, G. E. and Bras, R. L.: A stochastic approach to modeling the role of rainfall variability in drainage basin evolution, Water Resour. Res., 36, 1953-1964, https://doi.org/10.1029/2000wr900065, 2000.

Tucker, G. E. and Hancock, G. R.: Modelling landscape evolution, Earth Surf. Proc. Land., 35, 28-50, https://doi.org/10.1002/esp.1952, 2010.

Tucker, G. E. and Slingerland, R.: Drainage basin responses to climate change, Water Resour. Res., 33, 2031-2047, https://doi.org/10.1029/97wr00409, 1997.

Vandenberghe, J.: TIMESCALES, CLIMATE AND RIVER DEVELOPMENT, Quaternary Sci. Rev., 14, 631-638, https://doi.org/10.1016/0277-3791(95)00043-o, 1995.

Van De Wiel, M. J., Coulthard, T. J., Macklin, M. G., and Lewin, J.: Embedding reach-scale fluvial dynamics within the CAESAR cellular automaton landscape evolution model, Geomorphology, 90, 283-301, https://doi.org/10.1016/j.geomorph.2006.10.024, 2007. 
Wasko, C. and Sharma, A.: Global assessment of flood and storm extremes with increased temperatures, Sci. Rep.-UK, 7, 7945, https://doi.org/10.1038/s41598-017-08481-1, 2017.

Wasko, C., Sharma, A., and Westra, S.: Reduced spatial extent of extreme storms at higher temperatures, Geophys. Res. Lett., 43, 4026-4032, https://doi.org/10.1002/2016g1068509, 2016.

Westra, S., Alexander, L. V., and Zwiers, F. W.: Global Increasing Trends in Annual Maximum Daily Precipitation, J. Climate, 26, 3904-3918, https://doi.org/10.1175/jcli-d-12-00502.1, 2013.

Westra, S., Fowler, H. J., Evans, J. P., Alexander, L. V., Berg, P., Johnson, F., Kendon, E. J., Lenderink, G., and Roberts, N. M.: Future changes to the intensity and frequency of short-duration extreme rainfall, Rev. Geophys., 52, 522-555, https://doi.org/10.1002/2014RG000464, 2014.

Wright, D. B., Smith, J. A., Villarini, G., and Baeck, M. L.: Estimating the frequency of extreme rainfall using weather radar and stochastic storm transposition, J. Hydrol., 488, 150-165, https://doi.org/10.1016/j.jhydrol.2013.03.003, 2013.
Yakir, H. and Morin, E.: Hydrologic response of a semi-arid watershed to spatial and temporal characteristics of convective rain cells, Hydrol. Earth Syst. Sci., 15, 393-404, https://doi.org/10.5194/hess-15-393-2011, 2011.

Zhu, Z. H., Wright, D. B., and Yu, G.: The Impact of Rainfall SpaceTime Structure in Flood Frequency Analysis, Water Resour. Res. 54, 8983-8998, https://doi.org/10.1029/2018wr023550, 2018.

Zi, T., Kumar, M., Kiely, G., Lewis, C., and Albertson, J.: Simulating the spatio-temporal dynamics of soil erosion, deposition, and yield using a coupled sediment dynamics and 3D distributed hydrologic model, Environ. Modell. Softw., 83, 310 325, https://doi.org/10.1016/j.envsoft.2016.06.004, 2016.

Zoccatelli, D., Borga, M., Viglione, A., Chirico, G. B., and Blöschl, G.: Spatial moments of catchment rainfall: rainfall spatial organisation, basin morphology, and flood response, Hydrol. Earth Syst. Sci., 15, 3767-3783, https://doi.org/10.5194/hess-15-37672011, 2011. 